\title{
Daniel Bonini
}

“CORRELAÇÃO ENTRE BIOQUÍMICA CELULAR E NECROSE TECIDUAL EM REGIMES DE FRACIONAMENTO DE DOSE DE LUZ EM TERAPIA FOTODINÂMICA”

Dissertação apresentada ao Instituto de Química de São Carlos da Universidade de São Paulo para obtenção do título de Mestre em Ciências (Química Analítica)

Orientadora: Profa. Dra. Janice Rodrigues Perussi 


\section{DEDICATÓRIA}

Dedico este trabalho à minha família por se constituírem diferentemente enquanto pessoas, igualmente belas e admiráveis em essência, estímulos que me impulsionaram a buscar vida nova a cada dia, meus agradecimentos por terem aceitado se privar de minha companhia pelos estudos, concedendo a mim a oportunidade de me realizar ainda mais. 


\section{AgRADECIMENTOS}

Este espaço é dedicado àqueles que deram a sua contribuição para que esta dissertação fosse realizada. À todos eles deixo aqui o meu agradecimento sincero.

À minha orientadora Prof. Dra. Janice pela paciência, compreensão e ensinamentos em uma área do conhecimento que já gostava e aprendi a gostar ainda mais.

Ao Prof. Dr. Vanderlei Bagnato pelo apoio e incentivo durante todo período da realização dessa dissertação, e por valorizar, fundamentalmente, a capacidade e o potencial do ser humano como agente modificador do seu meio.

Ao meu pai, Fernando, pelo apoio incondicional, pelo amor, pelo carinho e pelos ensinamentos de vida em que sempre com muito jeito mostrava-me que sonhar é fundamental desde que mantivéssemos um algo de razão para nos questionarmos.

À minha mãe, Telma, pelo carinho, pelo afeto, pela garra e força e pelo amor de mãe tão verdadeiramente presente a todo o momento e que me foram base e sustentação do que hoje sou.

Aos meus irmãos, Eduardo e Arthur e minha avó materna Zélia, pelo companheirismo, preocupação, interesse e apoio aos meus novos passos no meu novo mundo como pesquisador.

Às minhas grandes amigas Lílian Tan Moryiama e Juliana Ferreira pela dedicação e amizade doadas, pelas noites despendidas na ajuda da realização dos experimentos, pelas discussões que muito acrescentaram à dissertação, pela minha adoção ao laboratório de biofotônica, fazendo-me sentir tão confortavelmente “em casa”.

Aos companheiros e amigos do laboratório de biofotônica, Cristina, Clóvis, Denis, Emery, Eurico, Priscila e Vitória; do LIEPO, Matão, Daniel, e do Laboratório de Bioquímica da USP de Ribeirão Preto, Prof. Dr. Orlando Castro e Silva Jr., Maria Eliza, Clarice, Maria 
Picinato, Maria Cecília e do Laboratório de Patologia da USP de Ribeirão Preto, Prof. Dr. Sérgio Zucoloto, Laura e Márcia, que sem o apoio seria impossível a realização dessa dissertação.

À Maria Silvia de Guzzi Plepis e à Andréia Cristina Cardozo de Moraes, do serviço de pós-graduação pela competência com que realizam seu trabalho e o carinho durante esse tempo de convivência.

Ao grande amigo pela revisão dos textos dessa dissertação.

Aos meus amigos-irmãos que sempre estiveram ao meu lado, fazendo-me lembrar a cada instante o quanto sou importante em suas vidas e não me deixando esquecer o enorme valor das antigas e das novas amizades.

E finalmente, a todos os amigos e colegas do Instituto de Física e Instituto de Química de São Carlos, FMUSP-RP e Unicamp que tornaram esse período de aprendizado e convivência mais prazeroso e agradável. 
“Alguns olham para as coisas que existem e se perguntam por quê? Eu sonho com o que não existe e me pergunto por que não?”

George Bernard Shaw 


\section{RESUMO}

Terapia fotodinâmica (TFD) é uma modalidade terapêutica pouco invasiva e sem efeitos térmicos aprovada para o tratamento de doenças neoplásicas e vasculares proliferativas, capaz de produzir necrose tecidual seletiva através de administração de um fármaco fotossensibilizador seguido da aplicação de luz em comprimento de onda adequado. Na presença de luz o fotossensibilizador passa à forma ativada, e na presença de oxigênio molecular presente nas células, produz espécies reativas de oxigênio e oxigênio singleto que induzem as células alteradas à morte. O melhor entendimento dos mecanismos e da resposta celular à TFD, a disponibilidade de fontes de luz mais baratas, confiáveis e de fácil manuseio, bem como bons resultados em pesquisa clínica, dão credibilidade à técnica e a sua difusão na prática clínica. Estudos recentes em dosimetria têm mostrado melhores resultados terapêuticos com o fracionamento da dose de luz uma vez que permite a reoxigenação dos tecidos durante o período em que esse não está sendo iluminado. Neste estudo, investigou-se o dano tecidual (profundidade de necrose) e os danos celulares, especificamente na mitocôndria (estado 3, estado 4, taxa do controle respiratório, relação de ADP/O, potencial de membrana e intumescimento ou "swelling”) do fígado normal de rato submetendo-o a regime de fracionamento da dose de luz. Vinte e cinco ratos Wistar receberam $1.5 \mathrm{mg} / \mathrm{kg}$ do fotossensibilizador Photogem 30 minutos antes da iluminação com laser de diodo $(\lambda=$ 630nm), potência $200 \mathrm{~mW}$, intensidade $250 \mathrm{~mW} / \mathrm{cm}^{2}$ e dose total fixa de $200 \mathrm{~J} / \mathrm{cm}^{2}$. Os animais foram divididos em 5 grupos de 5 animais, cada um sendo iluminado em intervalos diferentes de claro (C) e escuro (E): 800s, 400s, 200s, 100s e 50s, alternando, respectivamente nesses grupos, os períodos de C/E em 800s/0s, de 400s/400s, de 200s/200s, de 100s/100s e de 50s/50s. Os animais foram mortos 30 horas após a aplicação do Photogem. O tecido iluminado foi submetido à análise histológica. As lâminas histológicas mostraram uma tendência de aumento na profundidade de necrose, com um aumento de até 30\% em 
comparação ao regime contínuo e também uma tendência de diminuição na RCR e na relação ADP/O em função do tempo de escuro, principalmente até 200s do intervalo de C/E. Com tempo do fracionamento menor, as tendências de ADP/O e de RCR se invertem. O intumescimento e o potencial de membrana não mostraram diferença significativa com os diferentes regimes de iluminação. Conclui-se que o aumento de eficiência em PDT devido ao fracionamento da dose de luz é proporcionado pela maior disponibilidade de oxigênio na área tratada o que pode ocorrer pela reversão da oclusão vascular provisória ou do menor consumo de oxigênio pela reação fotodinâmica até o esquema do fracionamento da dose de luz de 200s. Para intervalos de escuro maiores tem-se uma limitação da reposição do oxigênio com conseqüente redução dos danos mitocondriais. O regime de fracionamento de dose de luz melhora a eficácia da técnica de PDT e mostra uma relação causal com a profundidade de necrose, embora a determinação da extensão dos intervalos de escuro seja fundamental para o sucesso da técnica.

Palavras-chave: Terapia Fotodinâmica; fracionamento; dose de luz; fígado; mitocôndria; Photogem 


\begin{abstract}
Photodynamic therapy is a promising minimally invasive and non-thermal therapeutic modality approved for the treatment of neoplastic and vascular disease, which produces localized tissue necrosis with light following admistration of a photosensitizing drug. The drug is activated by light of a specific wavelength. The activated photosensitizer, in the presence of oxygen, generates singlet oxygen and reactive oxygen species that will induce selected cells to death. The current best understanding of PDT mechanisms and cellular response, the availability of cheaper, trustworthy and easy handling sources of light, as well as good results in clinical investigations, had provided trustworthiness to the technique and its diffusion in clinical practice. Recent dosimetry studies had suggested better therapeutical results with dose light fractionation. In this study, it was investigated the tissue damage (depth of necrosis) and cellular damage specifically in the mitochondria (state 3 , state 4 , respiratory control rate (RCR), $\mathrm{ADP} / \mathrm{O}$ ratio, swelling and membrane potencial) in normal rat liver submitted to the fractionation of the light dose scheme. Twenty five Wistar rats received 1,5 $\mathrm{mg} / \mathrm{kg}$ of the first generation Russian photossensitizer Photogem ${ }^{\circledR} 30$ minutes before illumination with diode laser $(\lambda=630 \mathrm{~nm})$, power $200 \mathrm{~mW}$, fluence rate $250 \mathrm{~mW} / \mathrm{cm}^{2}$ and fluence $200 \mathrm{~J} / \mathrm{cm}^{2}$. Animals had been divided into 5 groups of 5 animals each, being illuminated in different intervals of light and dark (L/D): $800 \mathrm{~s}, 400 \mathrm{~s}, 200 \mathrm{~s}, 100 \mathrm{~s}$ and $50 \mathrm{~s}$, for each one had respectively alternated light/dark photodynamic therapy intervals of $800 \mathrm{~s} / 0 \mathrm{~s}$, $400 \mathrm{~s} / 400 \mathrm{~s}, 200 \mathrm{~s} / 200 \mathrm{~s}, 100 \mathrm{~s} / 100 \mathrm{~s}$ and $50 \mathrm{~s} / 50 \mathrm{~s}$. The rats were sacrificed 30 hours after Photogem application. The illuminated tissue was submitted to histological analyze. The histological sections of the illuminated tissue volume showed a trend toward increasing depth of necrosis (increase 30\%) as well as decreasing in RCR and ADP/O as a function of the increase in the dark interval, mainly until 200s of light interval. With lower fractionation time the trends of ADP/O and RCR becomes inverted. Swelling and membrane potencial did not
\end{abstract}


show significant difference in all fractionation schemes. It can be concluded that the enhancement of PDT efficiency by the fractionation of light is due to improved oxygen supply to the treated area, which may be due to the reversal of the temporary vascular occlusion or slower photochemical consumption of oxygen until 200s fractionation scheme. For higher light intervals there is a limitation in the oxygen replenishment leading to a reduction of the mitochondrial damage. A fractionated light dose delivery can enhance PDT efficiency with Photogem and presents a causal relation with necrosis depth, although the determination of the extension of the dark intervals is fundamental for the success of technique.

Keywords: photodynamic therapy, dose fractionation, liver, mitochondria, Photogem 


\section{Lista de Figuras}

FIGURA 1 - TAXA DE MORTALIDADE POR NEOPLASIA POR SEXO. (A) SEXO FEMININO, (B) SEXO MASCULINO (2001)

FIGURA 2 - PHOTOGEM E SUA ESTRUTURA MOLECULAR 11

FTGURA 3 - ESPECTRO DE ABSORÇÃo DO PHOTOGEM COM DETALHAMENTO PARA A BANDA DE SORET EM 370 NM E DAS BANDAS Q ENTRE 500 E $700 \mathrm{NM}$ 12

FIGURA 4 - ATIVAÇÃO DO AGENTE FOTOSSENSIBILIZADOR PELA LUZ. DIAGRAMA DE JABLONSKY. 16

FIGURA 5 - (A) LASER DE CORANTE BOMBEADO POR UM LASER DE ARGÔNIO. (B) LASER DE DIODO 17

FIGURA 6 - MECANISMO DE OCORRÊNCIA DO EFEITO FOTODINÂMICO. A - ACÚMULO DE DANO OXIDATIVO; A $_{\text {L }}$ DANO OXIDATIVO VITAL LIMIAR; FS - FOTOSSENSIBILIZADOR; FS* - FOTOSSENSIBILIZADOR ATIVADO 20

FIGURA 7 - ESTRUTURA MTTOCONDRIAL EM MTCROSCOPIA ELETRÔNICA DE VARREDURA 26

FIGURA 8 - SEQÜÊNCIA DE COMPLEXOS DO SISTEMA DE TRANSPORTE DE ELÉTRONS 28 FIGURA 9 - ALOJAMENTO DOS ANIMAIS MONTADO NO LABORATÓRIO DE BIOFOTÔNICA - INSTITUTO DE FÍSICA DE SÃO CARLOS - USP 36

FIGURA 10 - IRRADIAÇÃO DA REGIÃO DO FÍGADO ISOLADA PELA MÁSCARA DE ALUMÍNIO ENVOLTA POR GAZE _ 39

FIGURA 11 - DETALHE DA REGIÃo DO LOBO DIREITO DO FÍGADO IMEDIATAMENTE APÓS A IRRADIAÇÃO 45

FIGURA 12 - CORTE HISTOLÓGICO DA REGIÃo IRRADIADA DO FIGADO CORADO EM HEMATOXILINA-EOSINA (AUMENTO DE 100X) 46

FIGURA 13 - CORTE HISTOLÓGICO DE FÍGADO APÓS IRRADIAÇÃo CORADO EM HEMATOXILINA-EOSINA, DETALHE DA TRANSIÇÃO DO TECIDO NORMAL (ESQUERDA) E NECROSADO (DIREITA) (AUMENTO DE 400X) _ 46

FIGURA 14 - PROFUNDIDADE DE NECROSE EM FUNÇÃO DOS INTERVALOS DE CLARO/ESCURO NOS DIVERSOS GRUPOS DE REGIMES DE LUZ $(\mathrm{N}=5)$

FIGURA 15 - CONSUMO DE OXIGÊNIO NO ESTADO 3 DA RESPIRAÇÃO MITOCONDRIAL EM FUNÇÃO DE REGIMES DE FRACIONAMENTO DE LUZ NOS DIFERENTES INTERVALOS DE ESCURO 49

FIGURA 16 - CONSUMO DE OXIGÊNIO NO E4 DA RESPIRAÇÃO MITOCONDRIAL EM FUNÇÃO DE REGIMES DE FRACIONAMENTO DE LUZ NOS DIFERENTES NNTERVALOS DE ESCURO 
FIGURA 17 - TAXA DE CONTROLE DE RESPIRAÇÃO MITOCONDRIAL (RCR) EM FUNÇÃO DE REGIMES DE FRACIONAMENTO DE LUZ NOS DIFERENTES INTERVALOS DE ESCURO. 50

FIGURA 18 - TAXA DE ADP/O DA RESPIRAÇÃO MITOCONDRIAL EM FUNÇÃO DE REGIMES DE FRACIONAMENTO DE LUZ NOS DIFERENTES INTERVALOS DE ESCURO

FIGURA 19 - POTENCIAL DE MEMBRANA EM UNIDADE RELATIVA DE FLUORESCÊNCIA NOS DIVERSOS REGIMES DE ILUMINAÇÃO 54

FIGURA 20- VARIAÇÃO DO INTUMESCIMENTO OSMÓTICO MITOCONDRIAL NOS DIVERSOS GRUPOS DE ILUMINAÇÃO 


\section{LISTA DE TABELAS}

TABELA I - PRINCIPAIS FOTOSSENSIBILIZADORES 11

TABELA II - TTPO PRINCIPAIS DE FONTE DE LUZ PARA TFD 13

TABELA III - UNIDADES BÁSICAS USADAS EM TFD 22

TABELA IV - DIVISÃO DOS GRUPOS EXPERIMENTAIS $(\mathrm{N}=5)$ 38

TABELA V - PROFUNDIDADE DE NECROSE HEPÁTICA NOS GRUPOS COM DIFERENTES INTERVALOS DE REGIME DE $\operatorname{LUZ}(\mathrm{N}=5)$ 48

TABELA VI - DADOS REFERENTES A RESPIRAÇÃO MTTOCONDRIAL NOS DIFERENTES REGIMES DE FRACIONAMENTO $\operatorname{DE} \operatorname{LUZ}(\mathrm{N}=5)$

TABELA VII - POTENCIAL DE MEMBRANA (PM) E VARIAÇÃO DO INTUMESCIMENTO MITOCONDRIAL ( $\triangle$ SW) NOS DIVERSOS GRUPOS DE FRACIONAMENTO DE LUZ 


\section{Lista de Abreviaturas, Siglas e Símbolos}

A - dano tecidual

$\mathrm{A}_{\mathrm{L}}-$ limiar vital da célula

ADP - adenosina difosfato

$\mathrm{ADP} / \mathrm{O}$ - razão entre consumo de adenosina difosfato e oxigênio no respiração mitocondrial

ALA - ácido aminolevulínico

ANVISA - Agência Nacional de Vigilância Sanitária

ATP - adenosina trifosfato

$\mathrm{C} / \mathrm{E}$ - intervalo de claro e escuro

$\mathrm{cm}^{2}-$ centímetros quadrados

D - iluminação por via direta

EGTA - Ácido Egzático. Quelante mais específico para cálcio e menos tóxico que o EDTA.

EDTA - Quelante que sequestra uma variedade de cátions polivalentes

EROs - espécies reativas de oxigênio

FAD - flavina-adenina dinucleotídeo

FO - iluminação por fibra óptica

f - fração de espécies reativa de oxigênio

FS - fotossensibilizador / FS ${ }^{*}$ - fotossesibilizador em seu estado ativado

${ }^{3} \mathrm{~F}$ - Fotossensibilizador em seu estado fundamental

HEPES - Àcido 4-(2-hidroxietil)-1-piperazineetanossulfônico

HpD - derivado de Hematoporfirina

J - Joule

$\mathrm{Kg}$ - quilograma

$\mathrm{kDa}$ - kilodaltons

$\mathrm{L}-$ litro 
LDL - lipoproteína de baixa densidade (acrônimo de 'low density lipopretein')

LED - diodo emissor de luz (acrônimo de 'light-emitting diode')

$\mathrm{M}-\mathrm{mol}$

$\mathrm{mM}$ - milimolar

m-THPC - temoporfirina (Foscan $\left.{ }^{\circledR}\right)$

mg - miligrama

$\mathrm{mL}$ - mililitro

nm - nanômetro

$\mathrm{mW}$ - miliwatt

ns - nanossegundo

$\mathrm{N}$ - número de fótons

NAD - nicotidamida dinucleotídeo

$\mathrm{O}_{2} /{ }^{3} \mathrm{O}_{2} /{ }^{3} \mathrm{~W}_{\mathrm{g}}$ - oxigênio no estado fundamental / tripleto

${ }^{1} \mathrm{O}_{2}-$ oxigênio singleto

ppIX - protoporfirina IX

$\mathrm{pH}$ - potencial hidrogeniônico

$\mathrm{RCR}$ - razão de controle respiratório

${ }^{1} \mathrm{~S}_{0}-$ substratos biológicos

$\mathrm{s}$ - unidade de tempo em segundos

TFD - Terapia Fotodinâmica

W - Watt

$\mathrm{Z}$ - profundidade de necrose

$\lambda$ - comprimento de onda

$\Delta \Psi$ - gradiente eletroquímico

$\Phi$ - rendimento quântico 


\section{1 - INTRODUÇÃO}

\section{1 - A epidemiologia do câncer no Brasil}

Nos últimos anos, a população do Brasil vem sofrendo mudanças em sua estrutura demográfica, principalmente pelo aumento dos grupos etários mais idosos. O fato do envelhecimento populacional ligado à maneira como foram conduzidos os processos de colonização e desenvolvimento do Brasil até os dias de hoje, deixaram uma herança social que ainda traz conseqüências ao quadro sanitário brasileiro (INCA, 1997).

Uma das conseqüências mais importantes dessa herança é a coexistência das doenças ligadas à pobreza como as moléstias infecto-parasitárias ou as próprias do envelhecimento como as crônico-degenerativas, na lista das principais causa mortis do país. Essa peculiaridade faz existir em algumas regiões, como no Acre, taxas de mortalidadeproporcional entre doenças infecto-parasitárias e neoplasias muito parecidas, e em outras regiões como no estado do Rio Grande do Sul, essa diferença encontrada é de mais de quatro vezes (SAÚDE, 2001).

As neoplasias sempre figuraram entre as principais causas de morte em todas as regiões do país, ocupando na soma desses dados de todos os estados da federação, o segundo lugar entre as causas de morte. Há quase duas décadas a taxa de mortalidade por neoplasias malignas vem crescendo em todas as regiões brasileiras.

No Brasil foram diagnosticados 337.535 novos casos da doença em 2003. Os tumores malignos de pulmão, estômago e próstata foram mais freqüentes no sexo masculino; e no sexo feminino, foram mais freqüentes os de mama, colo do útero, pulmão e cólon (figura 1). As estimativas para o ano de 2006 são de 472.050 casos novos de câncer. Os tipos mais incidentes, à exceção dos tumores da pele não-melanoma que ocupam o primeiro lugar em 
ambos os sexos, serão os de próstata e pulmão no sexo masculino e mama e colo de útero no sexo feminino acompanhando o mesmo perfil de magnitude no mundo (INCA, 2005).

A

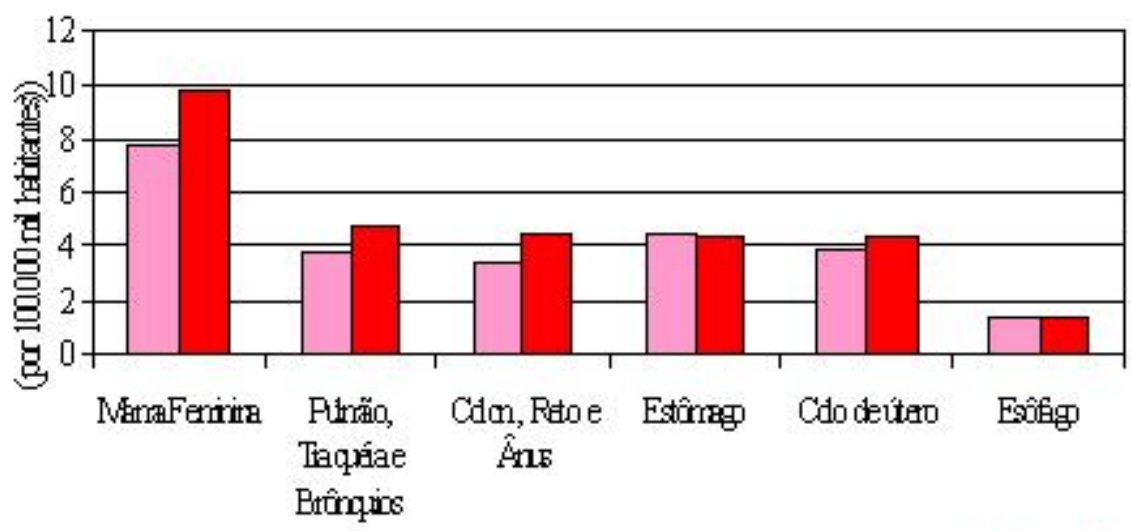

ㄴ1900 प1999

B

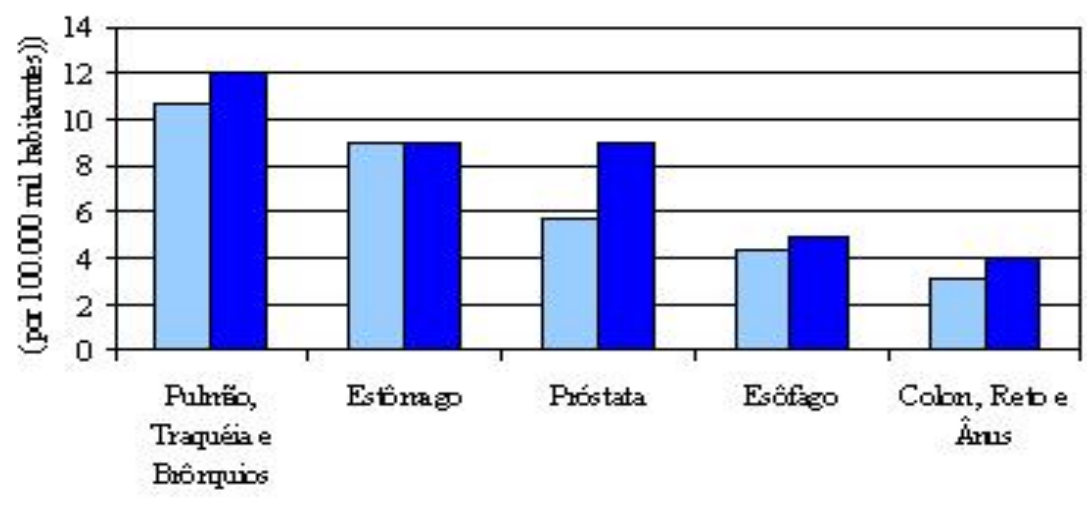

ㅁ1980 1999

Figura 1 - Taxa de mortalidade por neoplasia por sexo. (A) sexo feminino, (B) sexo masculino (2001)

A maioria dos pacientes com câncer procura cuidado especializado por sinais e sintomas decorrentes do resultado direto ou indireto do processo de evolução natural dessa doença. Acredita-se que no momento em que o câncer venha a trazer alguns desses sinais ou sintomas, já haja uma massa tumoral de pelo menos um milhão de células transformadas, fato 
esse que aumenta enormemente a chance de focos ectópicos, característicos de doença avançada e que define um pior prognóstico (INCA, 1997).

Atualmente a comunidade científica tem realizado esforços no desenvolvimento e implementação de novas técnicas para tratamento e diagnóstico relacionados às neoplasias. Para aumentar as possibilidades de cura do câncer, considerando os desanimadores resultados de tratamentos em casos de doença avançada, é necessário diagnóstico precoce, em que as células transformadas ainda não invadiram a membrana basal do tecido. Muitas vezes isso significa diagnóstico de carcinomas em sua fase assintomática com apoio de programas de assistência e conscientização da população (INCA, 1997).

1.2 - Terapia Fotodinâmica e o tratamento do indivíduo com câncer

A terapêutica do câncer mudou consideravelmente nos últimos cinqüenta anos, evoluindo de forma importante na agregação de conhecimentos. Essa evolução pode ser creditada ao sucesso dos avanços tecnológicos e científicos voltados para essa área. A oncologia mostrou o caminho para compreensão da variabilidade biológica do câncer e o sucesso que é possível com uma abordagem terapêutica multidisciplinar (BERTINO e HAIT, 2005).

Os resultados da terapêutica do câncer dependem de fatores que se relacionam ao indivíduo, ao tumor e às próprias opções de tratamento. Quanto aos aspectos individuais, deve-se conhecer o paciente por completo, considerar a condição clínica e psicológica, bem como as implicações do tratamento proposto aos seus aspectos sociais. A respeito do tumor, devem ser considerados o tipo celular, o grau de diferenciação, o estadiamento e o grau de resposta à terapêutica escolhida, que deve ser adequadamente escolhida e conhecida (INCA, 1997). 
No tratamento das neoplasias podem-se considerar a remoção cirúrgica do tumor, o uso da quimioterapia, o uso de radiação ionizante (radioterapia) ou ainda terapias biológicas, incluindo transplante medular, fatores de crescimento, uso de anticorpos antitumorais simples ou conjugados, interferons e citocinas, entre outros. Estas são consideradas as bases da maioria dos tratamentos disponíveis (BERTINO e HAIT, 2005).

Todas as formas de tratamento, quando bem indicadas e em estádios precoces da doença, têm mostrado boa eficácia. Apesar disso, ainda há situações em que as técnicas convencionais mostram-se sensivelmente limitadas, principalmente em neoplasias em estádio avançado ou quando há comprometimento anatômico-funcional do órgão ou tecido acometido (BERTINO e HAIT, 2005).

Além disso, os tratamentos apresentam inconvenientes, como internação hospitalar do paciente mesmo que para pequenas cirurgias, as necessárias margens de segurança que a cirurgia oncológica adota, podendo levar a deformidades no processo de recuperação, a menor seletividade das células doentes e sadias pela técnica de radioterapia e quimioterapia com efeitos colaterais importantes como mielossupressão, entre outros (BERTINO e HAIT, 2005).

Frente aos inconvenientes dos tratamentos convencionais, alternativas terapêuticas para o câncer são constantemente propostas pelo meio científico. No grupo dessas novas opções a terapia fotodinâmica (TFD) destaca-se como poderosa técnica para tratamento seletivo definitivo e/ou adjuvante. Essa técnica baseia-se na aplicação endovenosa de um fármaco fotoexcitável, chamado fotossensibilizador (FS), que se acumulará preferencialmente nas células alteradas, e então com a aplicação de luz no comprimento de onda $(\lambda)$ adequado, será ativado, produzindo oxigênio singleto e espécies reativas de oxigênio (EROs) a partir do oxigênio molecular presente no meio intracelular, levando então, a célula à morte (DOUGHERTY et al., 1998). 
A TFD é uma técnica relativamente recente em relação a outras opções de tratamento de neoplasias, e vários de seus aspectos vêm sendo alvo de estudo no intuito de alcançar a melhor relação custo-benefício e sua maior utilização como opção terapêutica do câncer.

Dentro dos aspectos de interesse em TFD, o estudo dosimétrico destaca-se como ponto fundamental ao ajuste fino dos resultados dessa nova técnica. Hoje aplicações em TFD apresentam dificuldades em prever a eficácia nas aplicações clínicas sem o controle das medidas quantitativas de suas variáveis dosimétricas.

\section{3 - Aspectos históricos da Terapia Fotodinâmica}

O uso da luz na terapêutica é conhecido pela humanidade há mais de três mil anos, quando os indianos usavam psoralenos no tratamento de vitiligo (ACKROYD et al., 2001), mas o conceito de morte celular sendo induzida por interação de substâncias químicas e a luz somente é empregado há pouco mais de cem anos.

O primeiro a observar e descrever essa interação foi Oscar Raab, no ano de 1900 em Munique, em que era estudante de medicina, durante seus estudos com acridina no tratamento de malária e constatou a morte de infusória, uma espécie de paramécio, quando exposta a certos comprimentos de onda da luz na presença de vermelho de acridina (RAAB, 1900). No ano seguinte, 1901, o médico neurologista francês J. Prime tratou epilepsia de uma paciente com eosina via oral, tendo como achado clínico a indução de dermatite nas áreas expostas à luz solar (PRIME, 1901). Essas descobertas levaram Von Tappeiner, em 1903, junto com o dermatologista A. Jesionek no que se configurou como primeira aplicação clínica usando eosina tópica e luz branca, no tratamento de tumores de pele (VON TAPPEINER e JESIONEK, 1903). Em 1904, von Tappeiner e Jodlbauer demonstraram a necessidade da presença do oxigênio para a ocorrência da reação encontrada (VON TAPPEINER e 
JODLBAUER, 1904), e descreveram esse efeito como "ação fotodinâmica" (VON TAPPEINER e JODLBAUER, 1907).

A partir daí foram descritos diversos estudos avaliando efeitos de fotossensibilidade e fototoxicidade, bem como farmacodinâmica e farmacocinética de fotossesibilizadores. Um dos marcos importantes da história da TFD aconteceu em 1975, quando Dougherty et al. obtiveram resposta completa no tratamento de tumor de cérebro de rato com o uso de derivado de hematoporfirina $(\mathrm{HpD})$ e fonte de luz vermelha (DOUGHERTY et al., 1975). No mesmo ano, 1975, o urologista J. F. Kelly em Londres, demonstrou que células tumorais de bexiga humana transplantadas em ratos poderiam ser tratadas e destruídas com a TFD (KELLY, SNELL e BERENBAUM, 1975).

Os estudos em humanos foram iniciados com Kelly e Snell em 1976 com o tratamento de cinco pacientes com câncer de bexiga, após tentativas de sucesso em modelo animal (KELLY e SNELL, 1976). O primeiro estudo clínico seriado de pacientes tratados com TFD ocorreu em 1978, com Dougherty, em que vinte e cinco pacientes com cento e treze lesões refratárias a tratamentos convencionais foram tratadas com $\mathrm{HpD}$, obtendo resposta completa em oitenta e sete por cento das lesões (DOUGHERTY et al., 1978), mostrando pela primeira vez a possibilidade do tratamento com sucesso de tumores mesmo refratários a outras terapias.

Desde então, muitos estudos têm sido publicados comprovando a eficácia da TFD. Lesões tumorais superficiais e de fácil acesso à luz foram tratadas com sucesso. Lesões maiores e mais profundas necessitavam de tratamento múltiplo, mas lesões menores geralmente eram tratadas com apenas uma aplicação e raramente deixavam cicatriz. Mesmo nos estudos iniciais, respostas completa no tratamento eram observadas em carcinomas basocelular (70-80\%), melanomas (50\%), metástases $(80 \%)$ e carcinoma espinocelular $(20 \%)$ (WILE et al., 1982; WILE et al., 1984). 
Y. Hayata et al., em 1982, sugeriram o uso da TFD por meio de broncoscópio para o tratamento de tumores de pulmão refratários à radioterapia com obstrução de vias aéreas, conseguindo importante melhora nos sintomas e na função ventilatória. No primeiro estudo, dos quatorze pacientes tratados, houve apenas um com resposta completa ao tratamento (HAYATA et al., 1982).

Em 1984, J. S. McCaughan et al. utilizaram a TFD para o tratamento de carcinoma de esôfago (MCCAUGHAN et al., 1984), O.J. Balchum et al., no mesmo ano, utilizaram a técnica para o tratamento de carcinoma pulmonar (BALCHUM, DOIRON e HUTH, 1984), e um ano mais tarde, Y. Hayata et al. utilizaram a TFD para tratamento de câncer gástrico (HAYATA et al., 1985). Todos esses estudos mostraram-se promissores no tratamento de pacientes com estadio baixo da doença. Após esses estudos, a TFD foi recomendada para o tratamento dessa condição nos pacientes para os quais não fosse indicada intervenção cirúrgica.

Há quase três décadas a TFD foi apontada como possível opção útil no tratamento de neoplasias, mas apenas nos últimos anos essa técnica está sendo mais utilizada na prática clínica (BROWN, BROWN e WALKER, 2004). Hoje, pacientes com câncer de mama (CUENCA et al., 2004), tumores ginecológicos (HILLEMANNS et al., 2006), tumores intraoculares e extra-oculares (WACHTLIN, BECHRAKIS e FOERSTER, 2005), tumores de sistema nervoso central (GOODELL e MULLER, 2001), tumores de cabeça e pescoço (LOU et al., 2004), tumores colorretais (DOHMOTO, HUNERBEIN e SCHLAG, 1996; VERIGOS et al., 2006), lesões de pele (SALOMON, 2005; GOLD e NESTOR, 2006), tumores intraperitoniais (WILSON et al., 2004), mesotelioma (FRIEDBERG et al., 2003), colangiocarcinoma (BERR, 2004), tumores de pâncreas (BOWN et al., 2002) têm beneficiado-se com a TFD. 
Hoje a experiência brasileira em TFD conta com aproximadamente 400 pacientes tratados em diversos centros clínicos por lesões de pele, laringe, nasofaringe, esôfago, bexiga e intestino (KURACHI et al., 2002). O processo ainda não é custeado pelo Sistema Único de Saúde e ocorre vinculado a centros de estudo e pesquisa no Brasil.

\section{4 - Mecanismos e processos em TFD}

O conceito de TFD é a indução de fototoxicidade letal nas células alteradas através de uma fonte de luz, um fármaco como agente fotossensibilizador (FS) e oxigênio molecular $\left(\mathrm{O}_{2}\right)$. A técnica de aplicação da TFD consiste na administração de um FS por via endovenosa, inalatória ou tópica, e após o período de acúmulo preferencial do fármaco nas células alteradas faz-se a aplicação de luz sobre a região a ser tratada (LAUSTRIAT, 1986).

Depois de transcorrido o intervalo fármaco-luz, que é definido para cada fármaco como período de acúmulo máximo nas células a serem tratadas, faz-se a aplicação da luz. A luz é aplicada na região dos tecidos alterados e também nos tecidos sadios que circundam a área a ser tratada. Os efeitos iniciais da ação fotodinâmica aos tecidos acontecem rapidamente, seguido pela seqüência de ações decorrentes da TFD, levando seletivamente os tecidos doentes à morte e preservação dos tecidos normais. A recuperação da área tratada dáse seis a oito semanas, com bons resultados estéticos (LAUSTRIAT, 1986).

A seletividade com que ocorre a destruição do tecido tumoral deve-se principalmente à maior concentração do fármaco fotossensibilizador nas células alteradas e às precisas fontes de luz responsáveis pela iluminação da totalidade das partes do tumor.

\subsection{1 - Fotossensibilizadores na prática clínica}


Um fotossensibilizador (FS) é definido como uma substância que induz sensibilidade luminosa a processos químicos e/ou físicos, normalmente insensíveis à luz. A maioria dos FS aprovados para uso clinico apresenta em sua estrutura em anel heterocíclico semelhante à clorofila e ao grupamento heme da hemoglobina. Os fótons são absorvidos na banda do espectro eletromagnético de absorção característica dos FS, podendo transferir esse energia a outras moléculas, especialmente ao oxigênio molecular que resultará na liberação de espécies energéticas de meia-vida curta, levando ao dano do sistema biológico envolvido (SIBATA et al., 2001).

Um FS ideal deve apresentar como características: ser puro, ter composição química conhecida, ser minimamente tóxico no período de escuro, ser preferencialmente retido no tecido alvo, rápida eliminação após o tratamento, não ser mutagênico/carcinogênico, ter mínimos efeitos colaterais, ter custo acessível, ter alto rendimento quântico, ter bandas de absorção dentro da janela biológica do espectro eletromagnético $(600-800 \mathrm{~nm})$, em que é maior a penetração da luz no tecido e o comprimento de onda suficientemente energético para ativação do FS levando à produção de oxigênio singleto (SHARMAN, ALLEN e VAN LIER, 1999).

A porfirina sódica foi o primeiro fármaco fotossensibilizador a receber aprovação para TFD e é composta de derivados de hematoporfirina (HpD), com seus componentes inativos (compostos pouco ou insensíveis a fotoativação) removidos. É comercializado em diversas proporções de monômero, dímeros e oligômeros de porfirina, como Photofrin ${ }^{\circledR}$, Photosan ${ }^{\circledR}$, Photocan ${ }^{\circledR}$, etc. (BONNETT e BERENBAUM, 1983), apesar da diferença de suas composições, suas formas comerciais parecem ser clinicamente equivalentes nos resultados (KESSEL et al., 1987). Algumas das vantagens dos derivados de hematoporfirina são destruir o tumor eficientemente, ser atóxica na ausência de luz, de preparação fácil para administração intravenosa e menor custo relativo. Como desvantagens, induz fotossensibilidade cutânea 
prolongada (MORIWAKI et al., 2001) e tem baixa seletividade aos tecidos tumorais nos períodos iniciais após administração endovenosa (GILSON et al., 1988).

Outros exemplos bastante difundidos na prática clínica são: temoporfirina, ácido aminolevulínico (ALA) e o Photogem ${ }^{\circledR}$. A temoporfirina (m-THPC) é um FS bastante ativo, requerendo menores doses de luz e de FS em comparação com a porfirina sódica. Além disso, este FS é um composto puro com uma forte absorção em $652 \mathrm{~nm}$. Também é associado com prolongada fotossensibilidade cutânea e pouco seletiva nos períodos iniciais após administração (SHARMAN, ALLEN e VAN LIER, 1999).

Todas as células têm o aparato celular necessário para a produção do grupamento heme, utilizado na síntese de hemoproteínas e citocromos. Um precursor do grupamento heme é a protoporfirina IX (PP-IX), a qual é um potente FS. A concentração desse FS no tecido alvo (neoplasia ou lesão pré-maligna) efetiva para a TFD, é conseguida com a aplicação tópica de ácido aminolevulínico (ALA) ou metil aminolevulanato, precursores da PP-IX. Esse achado levou a aprovação do ácido aminolevulínico nos Estados Unidos (EUA) e do metil aminolevulanato na União Européia (EU) para o tratamento com aplicação tópica desse FS em lesões de pele (BROWN, BROWN e WALKER, 2004).

Nenhum dos FS para aplicação endovenosa apresentados na tabela I foi desenvolvido para aplicação tópica em lesões cutâneas, apesar de inúmeras tentativas. Além disso, tentativas de injeção do FS diretamente nos tumores falharam, frente a esses fatos, parece haver a necessidade da administração do FS por via endovenosa para tratamento eficiente.

Muitas pesquisas têm sido feitas nos últimos 20 anos para o desenvolvimento de novos FS com propriedades otimizadas (Tabela I). Uma importante característica complementar dos FS está em sua capacidade de promover não só o tratamento do tumor, mas também possibilitar aplicações de métodos diagnósticos, como a biopsia óptica dos tecidos doentes através de suas propriedades de fluorescência. 
Tabela I - Principais fotossensibilizadores

\begin{tabular}{cccc}
\hline Classe & Nome do fármaco & $\begin{array}{c}\text { Banda de } \\
\text { Absorção } \\
(\mathbf{n m})\end{array}$ & $\begin{array}{c}\text { Coeficiente } \\
\text { de Absorção* }\end{array}$ \\
\hline Porfirinas & Porfirina sódica, Poliematoporfirina & 630 & 10000 \\
Clorinas & $\begin{array}{c}\text { Protoporfirina IX } \\
\text { Verteporfirina (derivado de benzoporfirina) } \\
\text { Temoporfirina (meta- }\end{array}$ & 633 & 10000 \\
Bacterioclorinas & tetrahidroxifenilclorina) & 690 & 35000 \\
Ftalocianinas & Ainda não aprovadas & 652 & 30000 \\
Compostos & Ftalocianina de alumínio sulfonada & 740 & 32000 \\
Fenotiazídicos & (mistura) & 680 & 110000 \\
Texafrinas & Ainda não aprovadas & 670 & 60000 \\
\hline
\end{tabular}

* Absorção de luz $\mathrm{cm}^{-1} \mathrm{~mol}^{-1} \mathrm{~L}^{-1}$

O Photogem (porfirina sódica), um FS de primeira geração derivado de hematoporfirina de origem russa (figura 2). Esse fármaco é aprovado pelo "Ministry of Public Health Service and Medical Industry of Russian Federation” sob autorização 42-3199-98. É produzido a partir de sangue de animais e sua preparação é feita no Instituto de Química Fina de Moscou.
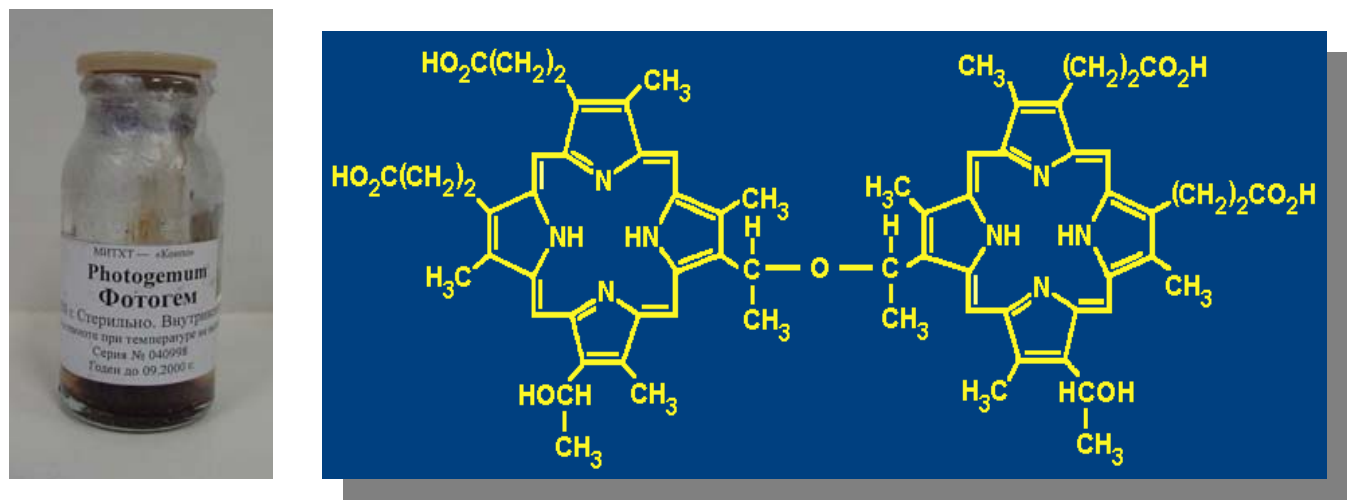

Figura 2 - Photogem e sua estrutura molecular 
O Photogem é aprovado para uso em humanos pelo comitê estatal de Farmacologia da Federação Russa e em 2003 foi aprovado pela ANVISA no Brasil (08/ 04/ 2003; processo 25351.189638/02-00; exp 132851/02-4). Este FS é constituído de uma mistura de monômeros e oligômeros de derivados de hematorporfirina. O produto é obtido em frascos de $50 \mathrm{~mL}$ contendo $200 \mathrm{mg}$ de Photogem que apresenta-se como um pó violeta escuro (Figura 2). O espectro de absorção de luz do Photogem apresenta um pico dentro da janela biológica em $630 \mathrm{~nm}$. A figura 3 apresenta o espectro de absorção do Photogem entre 300 e $700 \mathrm{~nm}$, com detalhamento das bandas entre 500 e $700 \mathrm{~nm}$.

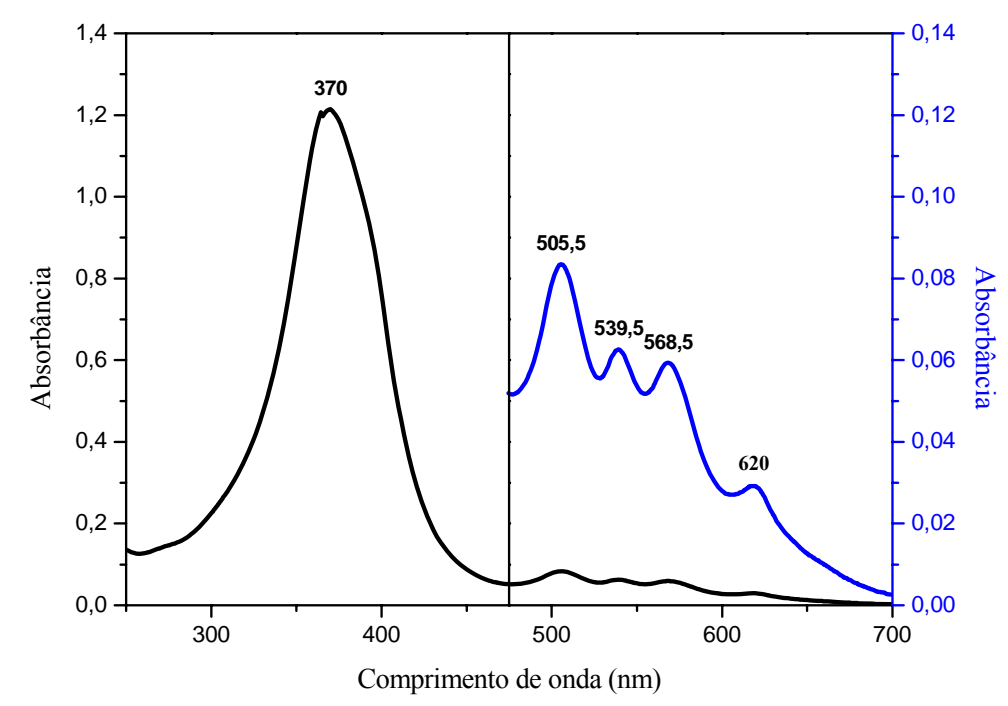

Figura 3 - Espectro de absorção do Photogem com detalhamento para a banda de absorção em $370 \mathrm{~nm}$ e entre 500 e $700 \mathrm{~nm}$ (bandas Q).

\subsection{2 - Fontes de luz em TFD}

As primeiras fontes de luz usadas em TFD foram lâmpadas convencionais em que o emissor era definido por filtros. A desvantagem do uso dessas fontes era o efeito térmico e a imprecisão para o cálculo dosimétrico, apesar de serem atraentes pelo preço e facilidade de 
uso. Historicamente, lasers de argônio e de vapor de metal são as escolhas iniciais para TFD, apesar do seu alto custo. Esses lasers combinam muitas características como alta potência, comprimento de onda ajustável, maior facilidade para o cálculo dosimétrico e a possibilidade de acoplamento a fibras ópticas para uso em procedimentos endoscópicos (NOWIS et al., 2005).

A região do espectro eletromagnético de emissão da fonte de luz para TFD deverá ser escolhida levando em consideração as bandas de absorção dos FSs e a profundidade desejável de penetração da luz nos tecidos biológicos (NOWIS et al., 2005).

Os lasers para geração de luz na região do vermelho (aproximadamente entre os comprimentos de onda de 625 - $740 \mathrm{~nm}$ ) mais utilizados para TFD são: laser de corante bombeado por um laser de argônio (com potência em torno de $3 \mathrm{~W}$ ), permitindo ampla variação de comprimento de onda, o suficiente para atuar em praticamente todos os FS já desenvolvidos; laser de diodo de alta potência (potência em torno de $2 \mathrm{~W}$ ), este sistema tem a limitação de operar em apenas um comprimento de onda, não possuindo a flexibilidade de ajuste de acordo com o fármaco a ser utilizado.

Como outras fontes de luz, pode-se citar os dispositivos a base de LEDs (acrônimo do inglês "light-emitting diodes") com as vantagens de serem menores, portáteis, confiáveis, de fácil manejo e comparativamente mais baratos do que as fontes de luz laser, com banda de emissão variando $5-10 \mathrm{~nm}$ e intensidade de $150 \mathrm{~mW} / \mathrm{cm} 2 \mathrm{em}$ áreas de até $20 \mathrm{~cm}^{2}$ sendo ajustável a área de irradiação. Como inconveniente, apresentam comprimento de onda fixo, dificultando o uso para mais de um FS e intensidade relativamente baixa, entretanto, o advento de novos avanços tecnológicos nessa área poderá melhorar esses aspectos desses aparatos (PATTERSON e WILSON, 1999).

Na Tabela II são apresentadas as principais fontes de luz que podem ser utilizadas em terapia fotodinâmica e suas características principais. 
Tabela II - Tipo principais de fonte de luz para TFD

\begin{tabular}{|c|c|c|c|c|c|}
\hline Fonte de Luz & $\begin{array}{c}\text { Comprimento de onda } \\
(\mathrm{nm})\end{array}$ & $\begin{array}{c}\text { Variacão do } \\
\lambda \\
\end{array}$ & $\begin{array}{c}\text { Intensidade } \\
(\mathrm{mW} / \mathrm{cm} 2)\end{array}$ & Pulso & $\begin{array}{c}\text { Meio de } \\
\text { aplicação* }\end{array}$ \\
\hline $\begin{array}{l}\text { Laser de } \\
\text { argônio }\end{array}$ & 488 e 514,5 & não há & 500 a 1.000 & não há & $\mathrm{D} / \mathrm{FO}$ \\
\hline $\begin{array}{c}\text { Laser de } \\
\text { argônio } \\
\text { pulsado com } \\
\text { laser de } \\
\text { corante }\end{array}$ & 500 a 750 & 5 a $10 \mathrm{~nm}$ & até 200 & não há & $\mathrm{D} / \mathrm{FO}$ \\
\hline $\begin{array}{l}\text { Laser de } \\
\text { vapor de } \\
\text { metal }\end{array}$ & Ultravioleta e visível & não há & até 10.000 & $\begin{array}{c}10 \mathrm{a} \\
50 \mathrm{~ns}\end{array}$ & $\mathrm{D} / \mathrm{FO}$ \\
\hline $\begin{array}{c}\text { Laser de } \\
\text { estado sólido }\end{array}$ & Nd:Yag 1064, 532,355, 266 & não há & até 10.000 & $\begin{array}{l}0,01 \mathrm{a} \\
30 \mathrm{~ns}\end{array}$ & $\mathrm{D} / \mathrm{FO}$ \\
\hline $\begin{array}{l}\text { Laser de } \\
\text { Diodo }\end{array}$ & 600 a 950 & não há & até 700 & não há & FO \\
\hline LED & Visível e Infravermelho & 5 a $10 \mathrm{~nm}$ & até 150 & não há & $\mathrm{D}$ \\
\hline
\end{tabular}

* D = Iluminação Direta / FO = Iluminação por fibra ótica

\subsection{3 - O processo fotodinâmico}

O mecanismo envolvido na distribuição preferencial dos sensibilizadores no tecido tumoral ainda não está completamente elucidado e acredita-se que as diferenças existentes entre o tecido tumoral e o tecido sadio contribuam para esta distribuição seletiva. Estudos com porfirina sódica (Photofrin) sugeriram algumas propriedades dos tecidos tumorais que diferenciariam a captação do FS em relação aos tecidos normais. Dentre as propriedades podem-se destacar (DOUGHERTY et al., 1998):

a) Presença de grande número de receptores de lipoproteínas de baixa densidade (LDL - acrônimo do inglês Low Density Lipoprotein): a captação do FS é controlada pela hidrofobicidade ou estado de agregação da droga. Fotossensibilizadores lipofilícos (tais como porfirinas ou ftalocianinas monossulfonadas) ou agregados de porfirina (tais como oligômeros de HpD) são transportados por lipoproteínas. Muitos tipos de células alteradas expressam um 
grande número de receptores de membrana para LDL devido à grande exigência de colesterol para a biossíntese de membrana plasmática e de organelas (MAZIERE et al., 1990), propiciando assim a maior captação do FS e definindo em parte sua distribuição no espaço intracelular.

b) Presença de macrófagos: foi demonstrado que os macrófagos associados a tumores captam grande quantidade de hematoporfirina, desempenhando função importante para o entendimento da maior seletividade aos tecidos neoplásicos (DOUGHERTY et al., 1998).

c) Baixos valores de potencial hidrogeniônico ( $\mathrm{pH}$ ) ( abaixo de 7,2 unidades de $\mathrm{pH}$ ) do espaço tecidual presente entre a membrana das células e as paredes dos vasos que irrigam os tecidos, chamado de terceiro espaço. $\mathrm{O}$ pH no terceiro espaço é mais baixo e em tecidos tumorais é freqüentemente menor do que o de tecidos normais pelo maior acúmulo de ácido lático. No tecido neoplásico a microvasculatura está alterada e o fluxo sangüíneo é insuficiente; conseqüentemente, as células tumorais passam a utilizar a via anaeróbica da respiração e produzem maiores quantidades de ácido lático, diminuindo o $\mathrm{pH}$ e aumentando a lipofilicidade do meio (DOUGHERTY et al., 1998). O pH de tecidos normais humanos situase, em condições normais, entre 7,2 e 7,4, enquanto que o $\mathrm{pH}$ de tecidos tumorais fica em torno de 6,77 (BONNETT, 1995).

d) A estrutura do estroma tecidual tumoral: caracteriza-se por aumento do terceiro espaço, presença de vasculatura fenestrada, drenagem linfática comprometida, grande quantidade de colágeno novo e uma grande quantidade de lipídeos, todos fatores relevantes ao maior acúmulo do FS. Além disso, a membrana celular das células tumorais é mais lipofílica (MAZIERE et al., 1990).

Durante a TFD, o FS presente na célula é ativado com a presença da luz. Essa ativação leva o FS do estado fundamental ao estado excitado chamado tripleto. Na etapa posterior, as moléculas do FS podem retornar ao estado fundamental emitindo energia, através da liberação 
de fótons ou progredir na cadeia de reações químicas. As moléculas de FS no estado tripleto podem sofrer três tipos de reações, duas delas com envolvimento de oxigênio (Figura 4).

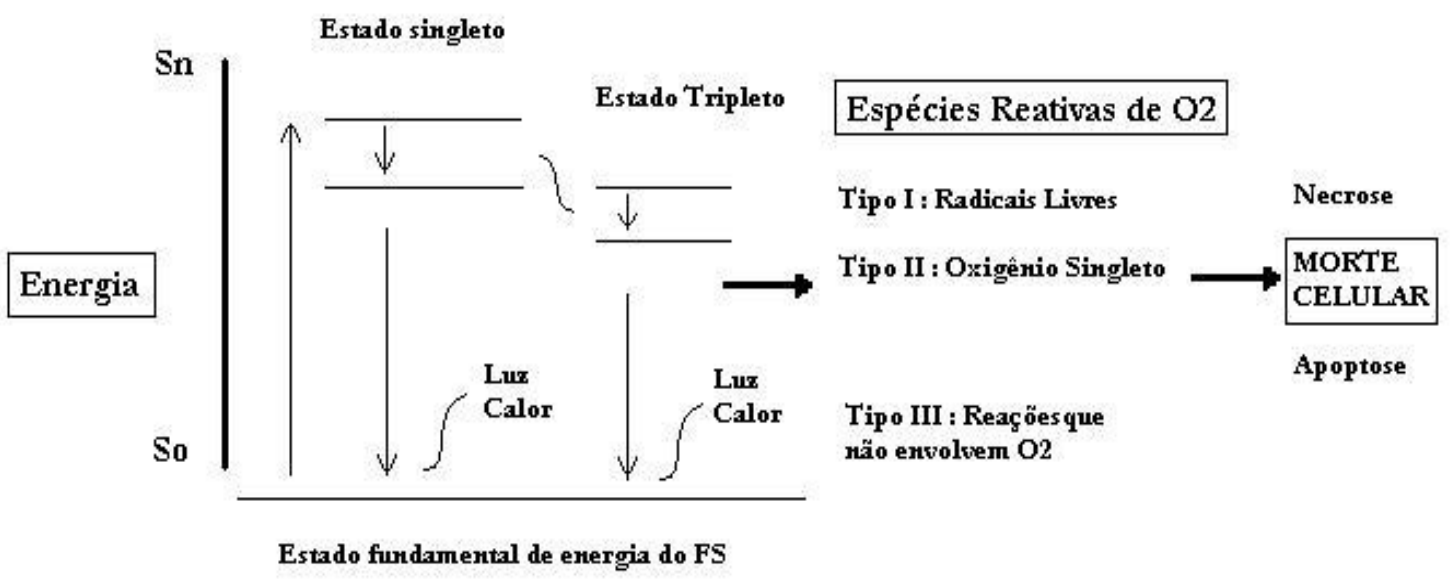

Figura 4 - Ativação do agente fotossensibilizador pela luz. Adaptação do Diagrama de Jablonsky.

Na reação do tipo I, as moléculas de FS no estado excitado $\left({ }^{3} \mathrm{~F}\right)$ interagem com os substratos biológicos $\left({ }^{1} \mathrm{~S}_{0}\right)$, gerando íons-radicais que tendem a reagir com oxigênio no seu estado fundamental - tripleto $\left({ }^{3} \mathrm{O}_{2}\right)$ para formar produtos oxidados. Em geral esse processo de transferência de elétrons tende a ser muito rápido, pois a sobreposição dos orbitais durante a formação do complexo excitado é máxima (KAVARNOS e TURRO, 1986). A natureza exata do processo dependerá das propriedades redóxi do FS no estado tripleto $\left({ }^{3} \mathrm{~F}\right)$ e do substrato biológico em seu estado fundamental $\left({ }^{1} \mathrm{~S}_{0}\right)$.

$\mathrm{Na}$ reação tipo II, as moléculas de FS excitadas $\left({ }^{3} \mathrm{~F}\right)$ transferem sua energia diretamente para o oxigênio em seu estado fundamental $\left({ }^{3} \mathrm{O}_{2}\right)$, formando o oxigênio singleto $\left({ }^{1} \mathrm{O}_{2}\right)$, forma molecular altamente reativa e considerada principal responsável pela morte celular (LAUSTRIAT, 1986). A reação tipo III representa fotorreações em que não está envolvida a participação do oxigênio. Oxigênio singleto é como são conhecidos os estados eletronicamente excitados imediatamente superiores ao oxigênio molecular no estado fundamental $\left({ }^{3} \Sigma_{\mathrm{g}}\right)$. A configuração eletrônica do oxigênio no estado fundamental possui dois 
elétrons desemparelhados nos orbitais moleculares degenerados, $\pi^{*} \mathrm{x}$ e $\pi^{*} \mathrm{y}$. Esses elétrons tendem a possuir o mesmo spin, de forma a produzir formas eletrônicas com mínima entalpia e máxima entropia, razão pela qual o estado fundamental do oxigênio é o tripleto $\left({ }^{3} \Sigma_{\mathrm{g}}\right)$ (COLUSSI, 1997). Os tipos de reações com o FS podem ocorrer simultaneamente e de forma competitiva, e a razão entre elas é influenciada pelas características do FS, substratos intracelulares e concentração de oxigênio no meio celular (SIBATA et al., 2000).

A região do espectro eletromagnético de emissão da fonte de luz para TFD foi escolhida levando em consideração as bandas de absorção do FS (Photogem) (figura 3) e a profundidade de penetração da luz nos tecidos biológicos. Apesar da região do vermelho do espectro eletromagnético não ser uma das bandas de absorção mais importantes do Photogem, o comprimento de onda usualmente empregado é o de $630 \mathrm{~nm}$, uma vez que se encontra dentro da janela biológica do espectro eletromagnético (600 a $800 \mathrm{~nm})$.

Caso o comprimento de onda de 505 ou $540 \mathrm{~nm}$ fossem os escolhidos, a reação fotodinâmica provocada não seria muito evidente, já que, apesar da maior absorção pelo FS, a penetração da luz no tecido biológico seria muito inferior àquela em $630 \mathrm{~nm}$, resultando em diminuição da profundidade de necrose.

Os lasers mais utilizados para esse tipo de FS para irradiação no comprimento de onda de $630 \mathrm{~nm}$, são os laser de corante bombeado por um laser de argônio (com potência de até de $3 \mathrm{~W}$ (figura 5A) e laser de diodo de alta potência de até de $2 \mathrm{~W}$, sendo que esse último sistema tem a limitação de operar em apenas um comprimento de onda (figura 5B).
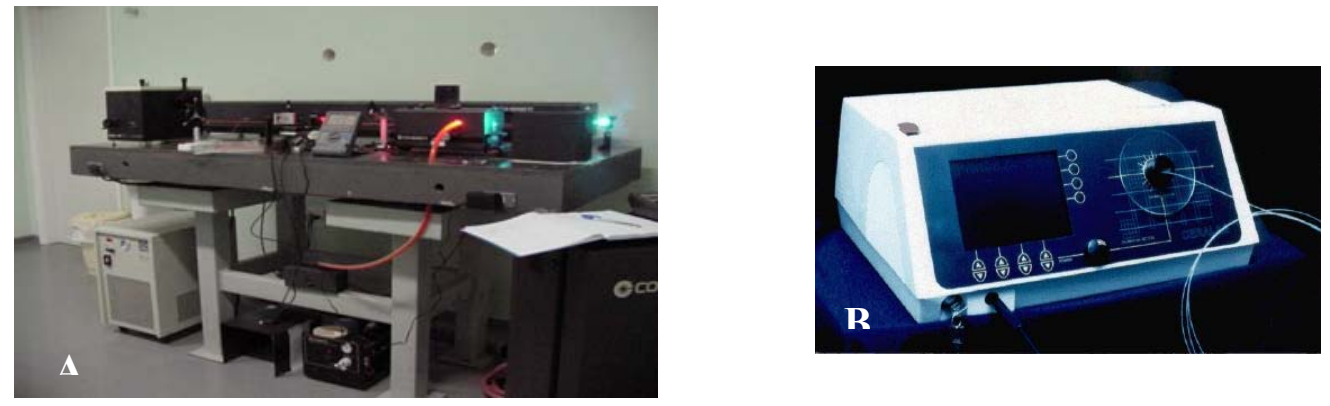

Figura 5 - (A) Laser de corante bombeado por um laser de argônio. (B) Laser de diodo 
1.4.4 - Mecanismos de destruição tumoral

Há três principais mecanismos de destruição tumoral pela TFD. O primeiro mecanismo é a geração de oxigênio singleto e espécies reativas de oxigênio (EROs) produzindo o dano direto às células tumorais, no segundo mecanismo o dano é causado à microvasculatura associada ao tumor bem como à do tecido sadio quando há presença de FS na corrente sanguínea, levando a vasoconstrição, trombose e infarto dos tecidos locais e finalmente, a TFD provoca ativação inespecífica do sistema imune. Esses efeitos interagem entre si produzindo repostas complexas. A importância relativa de cada um desses efeitos ainda não está bem definida, mas parece clara a necessidade de todos esses componentes para um controle a longo prazo da doença (DOUGHERTY et al., 1998).

A produção de oxigênio singleto é o mecanismo mais importante. Uma vez produzidos localmente causam danos às estruturas celulares alvos levando a célula à incompatibilidade funcional. Porém outros importantes mecanismos derivados desse efeito podem ser citados, como a indução da morte celular por apoptose, que pode ocorrer por alteração da membrana plasmática ou por via mitocondrial, através da inibição das proteínas da família Bcl-2, inibidoras da apoptose celular e ativação das caspases, proteínas iniciadoras e executoras da apoptose (OLEINICK, MORRIS e BELICHENKO, 2002).

A perturbação do suprimento sangüíneo do tumor devido à TFD pode levar à trombose, estase sanguínea e isquemia à jusante levando à conseqüente hipóxia e morte celular. O efeito térmico, condicionado pela absorção da luz pelos tecidos e FS presente nas células neoplásicas também pode causar dano celular, se não controlado, mas não é o desejável uma vez que a carbonização dos tecidos alteraria as propriedades ópticas da superfície do tecido influenciando mudanças na penetração da luz e resultados nos tecidos mais profundos. 
A viabilidade tumoral também depende do aporte de oxigênio e nutrientes proporcionado pelos vasos sanguíneos, isso faz com que esses sejam um alvo importante parar o tratamento do câncer. A TFD promove o colapso da microvasculatura local levando o tecido a uma importante hipóxia e anóxia. Estudos com HpD (Photofrin) demonstraram vasoconstrição, formação de trombos e inibição do crescimento tumoral. Por outro lado, a expressão dos genes do fator de crescimento endotelial vascular e da cicloxigenase-2 (ambos potentes fatores angiogênicos) estão superexpressos durante a TFD, provavelmente pela produção de EROs e pela hipóxia (DOLMANS, FUKUMURA e JAIN, 2003).

Em condições de anóxia ou hipóxia tecidual as células neoplásicas mostram-se resistentes à citotoxicidade induzida pela TFD (HENDERSON e FINGAR, 1989). Dessa forma, a diminuição da pressão parcial de oxigênio intracelular bem como dano à microvasculatura podem contribuir para o controle tumoral, mas também podem ser fatores limitantes da resposta tecidual à TFD (DOLMANS, FUKUMURA e JAIN, 2003).

Desde o final da década de 80 sabia-se do infiltrado inflamatório de linfócitos e macrófagos em tecidos após tratamento com PDT, sugerindo ativação da resposta inflamatória (HENDERSON e DOUGHERTY, 1992). O processo inflamatório é mediado por inúmeros fatores, como substâncias vasoativas, sistema complemento, fatores da cascata de coagulação, proteínas de fase aguda, proteinases, peroxidades, EROs, fatores de quimiotaxia, citocinas, fatores de crescimento entre outros fatores imunorreguladores. Esse processo está ligado à eliminação das células tumorais viáveis restantes após a PDT, garantindo o controle em longo prazo da doença (GOLLNICK et al., 1997; DOLMANS, FUKUMURA e JAIN, 2003). 


\section{5 - Dosimetria}

Com as aprovações realizadas pelas suas respectivas instituições reguladoras das técnicas em TFD no Brasil (2003) e em vários outros países, de vários fármacos fotossensibilizadores, fontes de luz e de técnicas de aplicação em TFD, a otimização dessa técnica torna-se prioridade para permitir condição e embasamento científico à transição de um tratamento experimental a uma técnica terapêutica aprovada por completo.

Alguns protocolos de aplicação clínica consideram pouco importantes fatores relevantes à resposta clínica, especialmente volume e dimensão dos tumores, bem como suas propriedades ópticas.

Há literatura considerável sobre modelos dosimétricos para TFD. Hoje, assume-se que a TFD é um processo em que uma densidade de energia mínima deve ser absorvida pelas moléculas de FS para que possa induzir a morte celular no tecido irradiado. O limiar até em que se tem necrose é bem caracterizado histologicamente e com borda bem definida, esse processo foi chamado de "threshold process", dando a idéia de limiar nas ocorrências dos processos na TFD (GROSSWEINER, 1997).

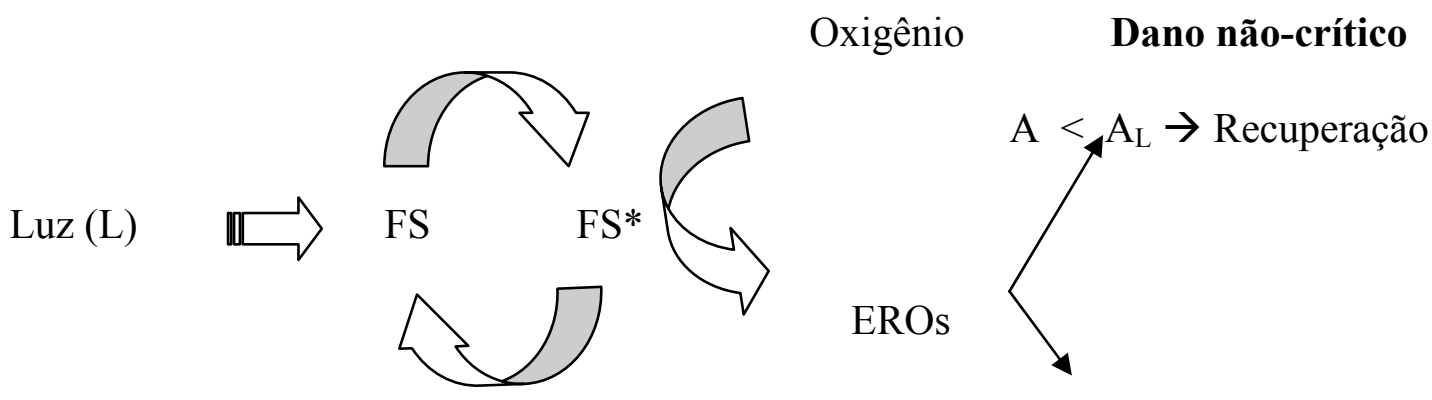

\section{Dano oxidativo crítico}

$$
\mathrm{A}>\mathrm{A}_{\mathrm{L}} \rightarrow \text { Morte Celular }
$$

Figura 6 - Mecanismo de ocorrência do efeito fotodinâmico. A - acúmulo de dano oxidativo; $\mathrm{A}_{\mathrm{L}}-$ dano oxidativo vital limiar; FS - fotossensibilizador; FS* - fotossensibilizador ativado 
Em termos atuais, como ilustrado na Figura 6, o efeito fotodinâmico depende da quantidade de luz entregue ao tecido (L) e da concentração de oxigênio molecular celular $\left({ }^{3} \mathrm{O}_{2}\right)$. A absorção da energia luminosa leva o FS ao seu estado ativado (FS*).

A interação do $\mathrm{FS}^{*}$ com a forma molecular do oxigênio leva à produção de EROs, especialmente oxigênio singleto. Uma fração (f) dessas EROs promoverá danos às regiões críticas na estrutura celular causando um acúmulo de dano oxidativo (A). Quando o acúmulo do dano oxidativo excede o limiar vital da célula $(\mathrm{A}>\mathrm{AL})$, então a morte celular ocorre.

Oxigênio é um dos três ingredientes chaves para a TFD (luz, FS e oxigênio) e a maioria dos cálculos dosimétricos assumem a concentração desse elemento como constante nos tecidos. Entretanto, as mudanças na perfusão sanguínea durante a TFD pode ocorrer levando-o a ser mais uma variável.

Determinar quantitativamente os fatores envolvidos em TFD é parte fundamental, pois esses fatores quando combinados, devem levar à eliminação do tumor com mínimo dano aos tecidos sadios adjacentes. O FS e oxigênio molecular e suas concentrações no tecido alvo são aspectos relevantes dentro da terapia; quando em baixas concentrações, não há o efeito fotodinâmico, comprometendo a eficácia da técnica. (FINGAR e HENDERSON, 1987; DOLMANS, FUKUMURA e JAIN, 2003).

As unidades básicas usadas para dosimetria em TFD são muitas (Tabela III) e devem ser consideradas na execução de protocolos clínicos nas lesões a fim de um ótimo resultado da técnica. Levar em consideração numa primeira abordagem todas essas inúmeras variáveis do estudo dosimétrico e sua complexa cinética em TFD a tornaria bastante dispendiosa de tempo e de meios de análise de resultados. Uma possível forma de contornar esse problema é relacionar a profundidade de necrose, resultado final de todo processo, com a dose de luz dada (GROSSWEINER, 1997; FERREIRA, 2003). 
Estudos mostram que os efeitos teciduais da TFD podem ser modulados reduzindo a taxa de fluência ou ainda introduzindo intervalos de escuro durante a iluminação sem alterar a dose total de energia, essa alteração no regime de iluminação, é chamada de fracionamento da dose de energia ou dose de luz (TSUTSUI et al., 2002).

Tabela III - Unidades básicas usadas em TFD

\begin{tabular}{|c|c|c|}
\hline & Nome (definição) & Conceito (símbolo) \\
\hline \multirow[t]{5}{*}{ FS } & Dose administrada & $\mathrm{mg} / \mathrm{kg}$ ou $\mathrm{mg} / \mathrm{m}^{2}$ \\
\hline & Concentração tecidual & $\mathrm{mg}$ fármaco/ $\mathrm{g}$ de tecido \\
\hline & Rendimento quântico & $\phi$ \\
\hline & Coeficiente de extinção & $\varepsilon \mu \chi\left(\left(^{1-}\right) \Lambda / \lambda \mathrm{o} \mu /\right.$ \\
\hline & $\begin{array}{l}\text { Comprimento de onda de } \\
\text { absorção }\end{array}$ & $\lambda \operatorname{abs}\left(\mathrm{nm}=10^{-9}\right)$ \\
\hline \multirow[t]{4}{*}{ Luz } & Número de fótons & $\mathrm{N}$ \\
\hline & Energia de fótons & Joule $(\mathrm{J})$ \\
\hline & $\begin{array}{l}\text { Densidade de energia, } \\
\text { Fluência ou Dose }\end{array}$ & $\begin{array}{l}\mathrm{J} / \mathrm{cm}^{2} \text { ou } \mathrm{J} / \mathrm{cm} \text { (difusor } \\
\text { cilíndrico) }\end{array}$ \\
\hline & $\begin{array}{l}\text { Irradiância, taxa de } \\
\text { fluência ou Intensidade }\end{array}$ & $\mathrm{W} / \mathrm{cm}^{2}$ \\
\hline Tecido & Penetração óptica & $\delta(\mathrm{cm})$ \\
\hline \multirow[t]{2}{*}{ Oxigênio } & $\mathrm{pO}_{2}$ & $\mathrm{~atm}=\mathrm{kgf} / \mathrm{cm}^{2}, \mathrm{mmHg}$, torr \\
\hline & Concentração & $\mathrm{mM}\left(10^{-6} \mathrm{M}\right)$ \\
\hline Resultados & Profundidade de necrose & $\mathrm{z}(\mathrm{cm})$ \\
\hline
\end{tabular}

1.6 - Fracionamento de dose de luz

O princípio imediato do fracionamento da dose de luz é permitir a reoxigenacão dos tecidos irradiados nos períodos de escuro. Com ausência de luz nesses períodos, a reação fotodinâmica pára, diminuindo o consumo do oxigênio molecular pela célula, permitindo o restabelecimento de seus valores máximos através da difusão desse gás dos capilares até as células, para então reiniciar o processo de iluminação. 
No tempo de escuro proporcionado pelo regime de fracionamento, além do restabelecimento da oxigenação dos tecidos, permite também o restabelecimento dos mecanismos de quelação de radicais livres e espécies reativas de oxigênio (EROs), a vasodilatação do vasos do tecido irradiado permite os danos causados pela reperfusão dos tecidos que mantiveram-se em condições hipóxicas e ainda possibilita a realocação do FS dentro do espaço celular.

A intensidade da luz, ou taxa de fluência, irá promover em última instância a produção de espécies reativas de oxigênio, especialmente oxigênio singleto, bem como, se não controlada a intensidade, poderá levar a efeito térmico dos tecidos e trombose de vasos.

Modelos de fracionamento de dose de luz em cultura de células e tecidos vivos foram investigados (MULLER et al., 1998; BORLE et al., 2003; TOGASHI et al., 2006), especialmente modificando o período dos intervalos de escuro. Esses períodos variavam desde alguns segundos até alguns dias. Estudos comparando os regimes de fracionamento de dose de luz têm mostrado um aumento dos efeitos para certas doses de energia e períodos de escuro (FOSTER et al., 1993; IINUMA et al., 1999).

O sucesso da técnica de fracionamento de luz aparentemente é dependente de inúmeros fatores, mas o ajuste principal faz-se na escolha do regime de fracionamento de luz e deve considerar entre outros pontos o tempo de escuro (esquema de dose de energia) e a intensidade de luz aplicada (taxa de fluência) (VAN GEEL et al., 1996). Esses efeitos serão limitados pelo tempo de difusão do oxigênio dos capilares à célula, desde que durante a aplicação da luz, o consumo de oxigênio pelo metabolismo celular e reações fotoquímicas sejam maiores do que a capacidade de oxigenação dos tecidos pelos vasos.

Sob condições convencionais de aplicação da técnica, a área irradiada é caracterizada por uma rápida queda da concentração de oxigênio molecular intracelular devido ao consumo de oxigênio pela reação fotodinâmica levando o tecido à condição de hipóxia. Sob essa 
condição a reação fotodinâmica pára, e conseqüentemente, os danos celulares também. A concentração intracelular de oxigênio é fundamental para que ocorra a reação fotodinâmica, pois a produção de oxigênio singleto e EROs é dependente da existência de oxigênio molecular no meio intracelular.

Com taxas de fluência mais baixas pode-se diminuir o consumo de oxigênio durante a aplicação da luz, mantendo as taxas de pressão parcial de oxigênio $\left(\mathrm{pO}_{2}\right)$ mais altas, permitindo maior rendimento na formação de EROs e levando assim a aumento no dano tecidual. Em contrapartida, taxas de fluência acima de $250 \mathrm{~mW} / \mathrm{cm}^{2}$ induzem um efeito térmico, por vezes significativo, podendo provocar fotodegradação dos FS, o que diminuiria o rendimento quântico da reação, além de uma degeneração térmica dos tecidos (VEENHUIZEN e STEWART, 1995).

Pogue e Hasan (1997) produziram um modelo matemático de consumo e difusão de oxigênio realizado tanto pelo metabolismo celular como por mecanismos fotoquímicos durante a iluminação na TFD; nesse estudo não foram levadas em consideração eventuais mudanças nas características dos tecidos durante a iluminação, como o aumento do tempo de reoxigenação por vasoconstrição ou trombose de vasos. Os resultados desse modelo foram comparados com resultados experimentais e chegou-se à sugestão de tempo ideal teórico de fracionamento de 30 a 60 s para um tecido hipotético com distância intercapilar de $1 \mathrm{~mm}$, em regimes de intervalos iguais de claro e escuro (POGUE e HASAN, 1997). Estudo parecido, realizado com melanoma e micro sensor de oxigênio chegou ao tempo de 20 a 50 segundos para o intervalo de fracionamento (ZILBERSTEIN et al., 1997).

A utilização de fracionamento de dose de luz com períodos de claro e escuro iguais tem a vantagem sobre os outros esquemas de permitir avaliar diferentes tempos de fracionamento mantendo a dose total de energia constante (FOSTER et al., 1991; POGUE e HASAN, 1997). 
No fracionamento de dose de luz deve-se ainda levar em conta o restabelecimento de sistema de inativação de radicais livres como o sistema glutationa. Durante o período de irradiação e produção de EROs e oxigênio singleto esses sistemas perdem eficiência por sobrecarga do aparato de inativação de radicais livres, permitindo maior ação desses sobre estruturas celulares. Em períodos de fracionamento de luz em que os intervalos de escuro são superiores a $60 \mathrm{~s}$, sistemas de quelação de radicais livres têm tempo de restabelecer sua função, dado que deve ser considerado em esquemas de fracionamento (OBERDANNER et al., 2005).

Num esquema de fracionamento de energia ideal teríamos o primeiro período iniciado com irradiação do tecido até a pressão parcial de oxigênio chegar a níveis menores que $2 \%$ da pressão parcial inicial, quando então a produção de oxigênio singleto pára. Em seguida o período de escuro seria iniciado e estender-se-ia até que a reoxigenação fosse máxima para iniciar um novo ciclo de iluminação. Esse esquema permite a produção mais eficiente de oxigênio singleto, pois não haveria período de claro com tecidos em hipóxia e nem período de escuro aguardando a reoxigenação máxima na célula que já esteja estabelecida (FOSTER et al., 1991; POGUE e HASAN, 1997).

Com o aumento da profundidade do tecido, a intensidade ou taxa de fluência diminui. Taxas de fluência muito baixas são incapazes de induzir células à morte, pois o dano oxidativo provocado nesses casos é insuficiente para ultrapassar o limiar vital da célula. Com o fracionamento da dose de luz era de se esperar um resgate de uma fração de tecido em que a taxa de fluência não fosse tão baixa a ponto de não produzir dano oxidativo, mas fosse suficiente alta para produzir dano oxidativo que somados nos vários períodos de claro produzissem um dano oxidativo total que ultrapassaria o limiar vital da célula induzindo-a a morte. 
As mitocôndrias são organelas encontradas em quase todas células eucarióticas. Sua função básica é a produção de adenosina trifosfato (ATP) a partir de substratos provenientes da alimentção, sendo a principal moeda de troca de energia na célula. Usado por uma gama de enzimas na execução das funções celulares, os organismos não poderiam viver, mesmo que por um momento, sem um suprimento adequado de ATP.

A mais imediata função dos sistemas circulatório e respiratório é eliminar o dióxido de carbono e suprir os tecidos de oxigênio, o qual será utilizado pelas mitocôndrias como aceptor final de elétrons.

As mitocôndrias variam consideravelmente em forma e tamanho, mas todas mantêm a mesma arquitetura básica (figura 7). Há uma membrana externa lisa formada por uma bicamada fosfolipídica contendo proteínas estruturais chamadas porinas, as quais permitem passagem de moléculas de até 10 kilodaltons $(\mathrm{kDa})$ ou menores. Dentro dessa membrana externa há uma membrana interna com inúmeras cristas, composta por uma estrutura que contém todos os complexos do sistema de transporte de elétrons, a ATP-sintase e proteínas de transporte, sendo permeável a oxigênio, dióxido de carbono e água.

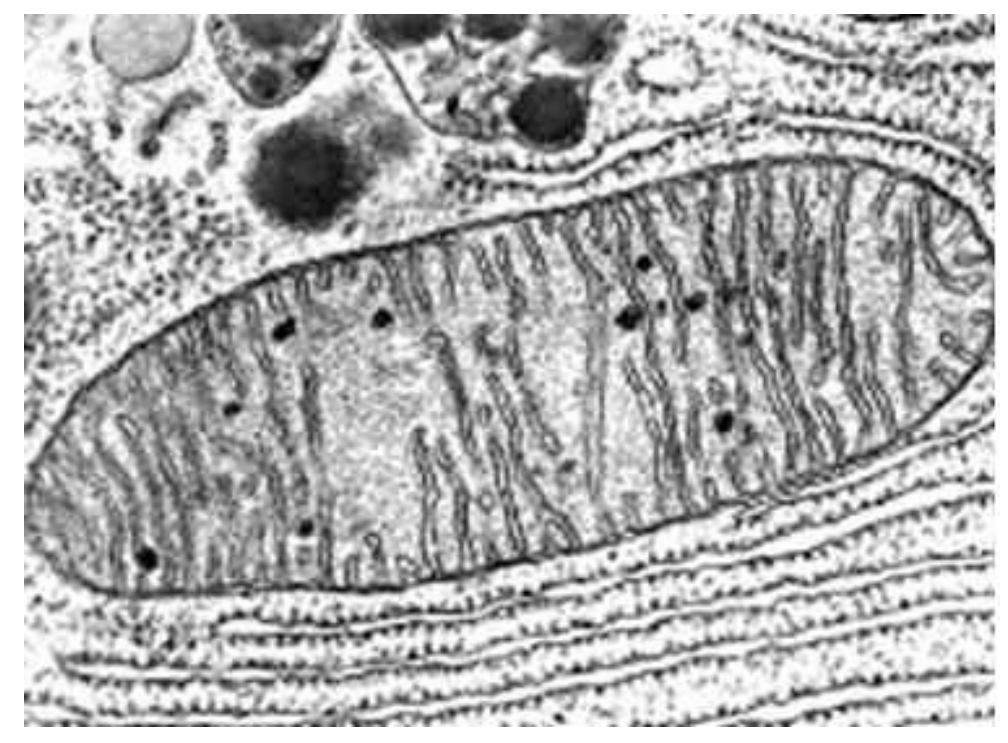

Figura 7 - Estrutura mitocondrial em microscopia eletrônica de varredura Fonte : Molecular Biology of the Cell: Garland. 2002. 1616 p. 
As membranas criam dois compartimentos na estrutura mitocondrial, uma região entre membranas, chamado de espaço intermembranas que desempenha importante função no processo de fosforilação oxidativa e o espaço delimitado pela membrana interna que é chamado de matriz mitocondrial e contém as enzimas responsáveis pelo ciclo de Krebs.

O ciclo de Krebs, ou ciclo do ácido cítrico ou tricarboxílico, é uma seqüência de reações mediadas por enzimas com a função de oxidar os substratos em um processo cíclico. O substrato mais reduzido, isto é com maior energia livre, é o ácido cítrico (citrato); em contrapartida o mais oxidado, com menor energia livre, é o ácido oxalacético (oxalacetato). O ácido cítrico pode ser regenerado pelo acoplamento do oxalacetato a duas unidades de carbonos, no caso do ciclo de Krebs, o acetil coenzima-A.

O acetil coenzima-A, gerado a partir do metabolismo de gorduras e açúcares, restabelece a energia livre do sistema. Outra forma de adicionar mais energia é a conversão de vários aminoácidos a intermediários do ciclo.

Em certos pontos do ciclo, as enzimas responsáveis pela reação conservam a energia livre reduzindo moléculas de nicotidamida-adenina dinucleotídeo $\left(\mathrm{NAD}^{+}\right)$ou flavina-adenina dinucleotídeo (FAD), que funcionam como receptores de hidrogênio, dessa forma a oxidação fica associada a uma redução.

Esses dinucleotídeos em sua forma reduzida (NADH e $\left.\mathrm{FADH}_{2}\right)$ são carreadores de energia, e entregam essa energia para moléculas presentes na membrana interna mitocondrial, sendo então reoxidados. As moléculas presentes na membrana interna são carreadores de energia de tipo diferente dos dinucleotídeos citados, pois transferem energia por meio de transporte de pares de elétrons através de uma cadeia de reações. Juntas, as moléculas transportadoras de elétrons da membrana interna mitocondrial são chamadas de sistema de transporte de elétrons. 


\subsection{1 - Sistema de transporte de elétrons}

O sistema de transporte de elétrons é composto pelos complexos I, II , III e IV, além de duas moléculas individuais, a coenzima Q e o citocromo C (figura 8).

O NADH é reoxidado no complexo I (NADH-desidrogenase). O par de elétrons do NADH é passado do complexo I para a coenzima Q (complexo II, succinato-desidrogenase), liberando energia. Essa energia no complexo I, faz com que para cada par de elétrons que passe pela sua cadeia de reações, um par de prótons $\left(\mathrm{H}^{+}\right)$seja forçado a passar da matriz ao espaço intermembranas.

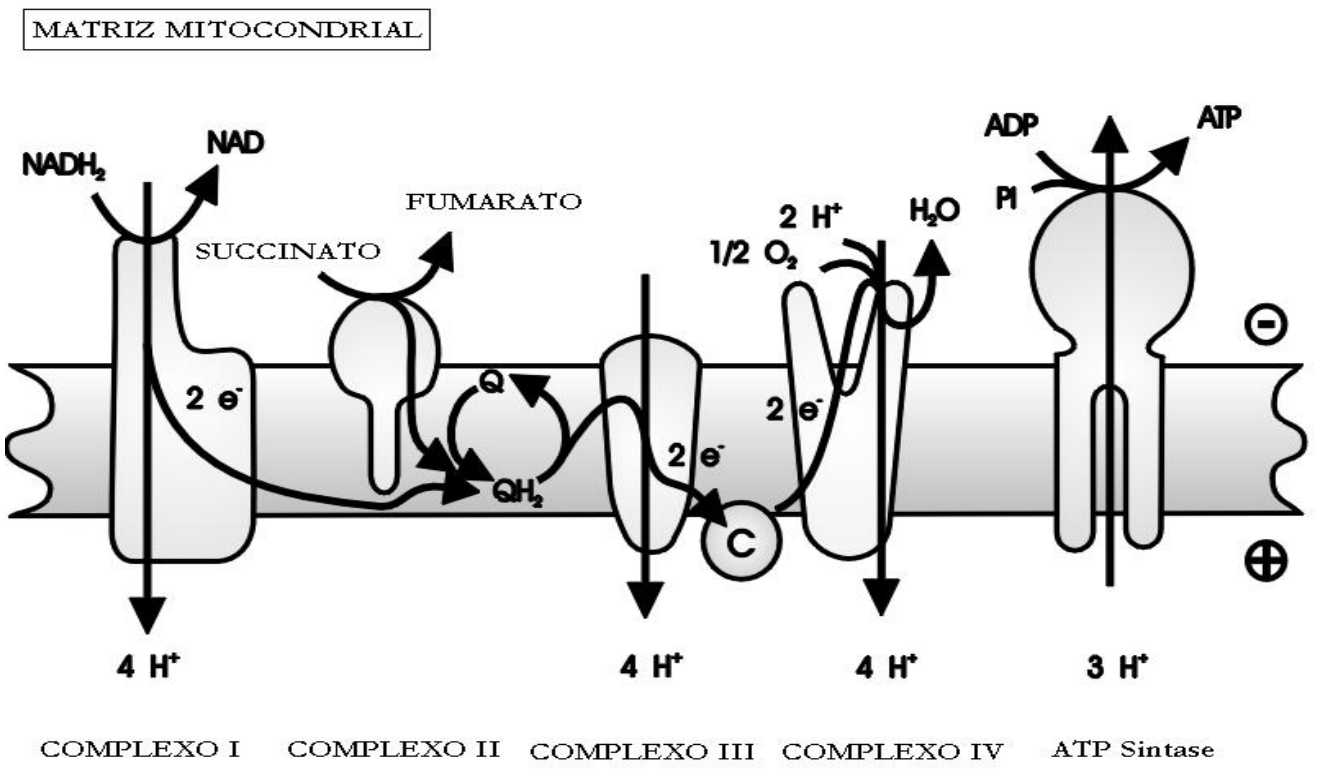

Figura 8 - Seqüência de complexos do sistema de transporte de elétrons Fonte : Molecular Biology of the Cell: Garland. 2002. 1616 p., adaptado.

O par de elétrons é então passado ao complexo III (Citocromo-c- redutase), em que mais prótons são forçados ao espaço intermembranas, bem como quando passam do complexo III ao IV. O complexo IV também chamado de citocromo-c-oxidase, utiliza a energia recebida para reduzir oxigênio a água. Dessa forma o oxigênio precisa ser reposto, caso contrário, o 
transporte de elétrons pára. Cada carreador, uma vez reduzido, assim permanecerá até que haja aceptores de seus pares de elétrons e essa é a função principal do oxigênio no final do sistema de transporte de elétrons. Na ausência de oxigênio todos os carreadores do sistema de transporte de elétrons permaneceriam reduzidos. A necessidade de suprir o sistema de transporte de elétrons com oxigênio é a responsabilidade mais imediata do sistema respiratório e circulatório.

Na transferência dos elétrons através dos carreadores o total de energia livre cai. Cada carreador é mais eletronegativo do que o imediatamente anterior. Parte da energia é perdida na forma de calor, mas uma quantidade significativa é armazenada na forma de gradiente de prótons no espaço intermembranas.

\subsection{2 - Gradiente eletroquímico $(\Delta \Psi)$ e controle respiratório}

O sistema de transporte de elétrons no processo de passagem de prótons para o espaço intermembranas, não pode fazê-lo infinitamente. As membranas interna e externa mitocondriais são impermeáveis aos prótons, dessa forma esses são acumulados no espaço intermembranas, criando o que é chamado de gradiente eletroquímico.

Esse potencial eletroquímico de $\mathrm{H}^{+}$, tem um componente elétrico que atinge cerca de 180 milivolts $(\mathrm{mV})$ no estado de repouso, e um componente químico que oscila de pH zero a 0,5. A enzima ATP-sintase promove o retorno dos íons $\mathrm{H}^{+}$à matriz e aproveita a energia liberada do potencial protônico para fosforilar adenosina difosfato (ADP).

A mitocôndria in vivo mantém seus gradientes de energia em níveis constantes. Essa situação é assim mantida em razão de mecanismos de controle. A manutenção desse gradiente é chamada de controle respiratório.

O transporte de elétrons não prossegue se prótons não forem bombeados para o espaço intermembranas. Prótons não podem ser bombeados para o espaço intermembranas a menos 
que a energia disponível para movê-los para fora da matriz mitocondrial exceda a quantidade de energia requerida para o processo de transporte mais a energia perdida em forma de calor.

De fato, o transporte de elétrons é estimulado pelo aumento da eletronegatividade dos sucessivos carreadores e pela disponibilidade de substratos para fornecer elétrons e energia livre, e limitado pelo gradiente eletroquímico $(\Delta \Psi)$ - o transporte de elétrons é estimulado proporcionalmente à energia perdida pelo gradiente eletroquímico.

Vários processos atuam no sentido de dissipar o gradiente eletroquímico do espaço intermembranas, mesmo em condições basais. Dessa forma o transporte de elétrons nunca pára totalmente, mantendo níveis mínimos de atividade, o principal processo de dissipação do potencial eletroquímico é o de fonte de calor para organismos homeotérmicos.

\subsection{3 - Fosforilação oxidativa}

Junto à membrana interna mitocondrial há estruturas chamadas de complexo ATPsintase. Esse complexo consiste basicamente em um canal de prótons e um sítio catalítico para a síntese de ATP a partir de ADP e íon fosfato. Quando ADP e fosfato estão disponíveis, eles ligam-se aos sítios da ATP-sintase, levando à abertura do canal de prótons e permitindo a volta desses à matriz mitocondrial. A energia envolvida no processo será usada para acoplar o fosfato ao ADP produzindo ATP.

O $\Delta \Psi$ pode também ser consumido, sem síntese de ATP, dissipando sua energia por exemplo, na forma de calor. Isso caracteriza o que é chamado de "desacoplamento" entre a respiração e a fosforilação oxidativa: os prótons ejetados da matriz da mitocôndria pela respiração retornam sem passar pelo canal de prótons da ATP-sintase, passo essencial para a fosforilação do ADP. 
1.7.4 - Respiração mitocondrial e Sistema polarográfico de medida de oxigênio dissolvido

O potencial elétrico da membrana mitocondrial pode ser aferido utilizando a mesma fração mitocondrial usada para determinação do consumo de $\mathrm{O}_{2}$ (método polarográfico). A membrana interna atua como sistema polarizado internamente com cargas negativas, que funcionam como sítios de ligação para corantes lipofílicos, por exemplo a safranina. É possível avaliar $\Delta \Psi$ quantificando o número de sítios de ligação. A intensidade de fluorescência indica, de maneira inversamente proporcional, o grau de energização da membrana interna, ou seja, o potencial de membrana. Uma vez estabilizado o $\Delta \Psi$, adiciona-se um desacoplador, o protonóforo FCCP [carbonil cianeto r-(trifluoro-metoxi) fenilhidrazona].

Esses ácidos lipossolúveis fracos podem transpor a barreira lipídica da membrana mitocondrial sem transitar pela ATP-sintase. Depois de entrar na matriz mitocondrial na forma protonada por outra via para o fluxo de $\mathrm{H}^{+}$que não a da ATP sintase, eles se dissociam do próton. Esse fato elimina o gradiente de prótons gerado pela cadeia transportadora de elétrons e, portanto, elimina o potencial de membrana. Há interrupção da síntese de ATP sem bloquear a captação de $\mathrm{O}_{2}$, pois tanto a oxidação de substratos, quanto o transporte de elétrons e o bombeamento de $\mathrm{H}^{+}$continuam, mesmo na ausência de ADP (LEHNINGER, NELSON e COX, 2000).

Princípio do método: O eletrodo tipo Clarck é constituído por um cátodo de platina acoplado a dois ânodos de prata através de uma ponte de cloreto de potássio $(\mathrm{KCl})$ saturada e cobertos por uma membrana de teflon. O oxígrafo mantém uma diferença de potencial entre os dois eletrodos de modo que o eletrodo de platina esteja carregado negativamente em relação ao eletrodo de prata.

Quando polarizado com 0,8 Volts o oxigênio dissolvido no meio de incubação é reduzido no cátodo de platina a íons $\mathrm{OH}^{-}$, de acordo com a reação: 


$$
\begin{aligned}
& \mathrm{O}_{2}+2 \mathrm{H}_{2} \mathrm{O}+2 \mathrm{e}^{-} \rightarrow \mathrm{H}_{2} \mathrm{O}_{2}+2 \mathrm{OH}^{-} \\
& \mathrm{H}_{2} \mathrm{O}_{2}+2 \mathrm{e}^{-} \rightarrow 2 \mathrm{OH}^{-}
\end{aligned}
$$

O circuito é completado pela seguinte reação, que ocorre no ânodo de prata:

$$
4 \mathrm{AgO}+4 \mathrm{Cl}^{-} \rightarrow 4 \mathrm{AgCl}+4 \mathrm{e}^{-}
$$

Assim, o fluxo de elétrons do ânodo de prata para o cátodo de platina produz uma corrente elétrica diretamente proporcional à quantidade de oxigênio presente no meio, que se difunde através da membrana de teflon, essa corrente é amplifica e registrada através de um potenciômetro.

\subsection{5 - Transição de Permeabilidade Mitocondrial (TPM) / Intumescimento osmótico}

Transição de permeabilidade foi primeiramente definida por HUNTER e HAWORTH (1979), os quais demonstraram um edemaciamento mitocondrial induzido pelo acúmulo de $\mathrm{Ca}^{2+}$, ocorrendo quando a mitocôndria passa de estado acoplado para o estado desacoplado e matriz mitocondrial expandida, permitindo a passagem de moléculas de baixo peso molecular $(\mathrm{PM}<1,5 \mathrm{kDa})$, componentes do suporte osmótico, caracterizando um aumento inespecífico da permeabilidade da membrana (ZORATTI e SZABO, 1995), levando a mitocôndria ao estado intumescido, chamado de intumescimento osmótico ou "swelling", em inglês.

O ponto chave da transição de permeabilidade é o acúmulo de $\mathrm{Ca}^{2+}$ na matriz mitocondrial. As quantidades de $\mathrm{Ca}^{2+}$ necessárias para o início do intumescimento variam entre espécies ou mesmo entres órgãos. Embora a adição de $\mathrm{Ca}^{2+}$ seja suficiente para induzir a transição de permeabilidade, este fenômeno pode ser acelerado por ação de algumas substâncias designadas indutores (ZORATTI e SZABO, 1995). 
O termo "transição" é usado porque a permeabilização pode ser em parte revertida, logo após o início do processo, pela adição de quelantes de $\mathrm{Ca}^{2+}$ ou agentes redutores. A formação do poro pode ser estimulada por compostos capazes de aumentar o estresse oxidativo mitocondrial: fosfato inorgânico, oxidantes de nucleotídeos de piridina e de grupamentos tiólicos, protonóforos (carreadores de prótons) e outros (KOWALTOWSKI e VERCESI, 1999). Reagentes capazes de interferir no estado redox dos grupos tiólicos também parecem estar envolvidos na indução de transição de permeabilidade. Dentre eles, destacam-se os metais pesados e de transição e seus complexos $\left(\mathrm{Hg}^{2+}, \mathrm{Cu}^{2+}, \mathrm{Zn}^{2+}\right)$, além das substâncias que induzem a formação de ligações cruzadas e pontes dissulfeto como a diamida e a n-etilmaleimida (GUNTER e PFEIFFER, 1990; ZORATTI e SZABO, 1995).

Um dos mecanismos propostos para explicar o fenômeno da TPM baseia-se na ligação do $\mathrm{Ca}^{2+}$ a sítios internos da membrana permitindo a abertura de um canal hidrofílico transmembrana. Este poro é regulado pela ligação de $\mathrm{Ca}^{2+}$ na membrana no lado da matriz, revertida por EGTA e inibido por $\mathrm{H}^{+}, \mathrm{Mg}^{2+}$ e nucleotídeos de adenina (HUNTER e HAWORTH, 1979).

Há evidências experimentais de que a TPM seria um evento essencial no processo de morte celular tanto por apoptose quanto por necrose. O aumento prolongado da concentração de $\mathrm{Ca}^{2+}$ no citosol e na matriz mitocondrial pode induzir essa permeabilização. Na morte celular por necrose, o teor de $\mathrm{Ca}^{2+}$ aumenta no citosol por falência dos mecanismos que promovem a retirada desse íon e a ocorrência da TPM generalizada leva à falta de ATP, seguida de morte celular.

Na morte por apoptose, a TPM seria um evento restrito aos locais de aumento do $\mathrm{Ca}^{2+}$ liberado de forma regulada pelo retículo endoplasmático. Nesse caso, a produção do ATP necessária para esse tipo de morte seria garantida por outras mitocôndrias não acometidas. Contrariando a opinião de alguns autores (BATANDIER, LEVERVE e FONTAINE, 2004) os 
quais afirmam que a abertura do poro de transição de permeabilidade induz a formação de espécies reativas de oxigênio, Kowaltowsky et al., 2001, afirmam que a transição de permeabilidade mitocondrial ocorre em resposta à formação de EROs. Assim sendo, durante este processo se abririam megacanais na membrana mitocondrial interna, também denominados de poros de transição de permeabilidade, o que resultaria no desacoplamento momentâneo da respiração e eliminação das ERO. Caso ocorresse, o fechamento dos poros e a retomada da respiração retornariam ao normal.

Se as EROs continuassem acumulando-se, os poros de transição continuariam abertos resultando no inchamento e posterior rompimento da organela. Tal rompimento, por sua vez, levaria à liberação no citosol de proteínas "suicidas", descritas na literatura como fatores indutores da apoptose (AIF - acrônimo do inglês "Apoptosis-inducing factor") ou fatores ativadores das caspases (APAF - acrônimo do inglês "Apoptotic protease activating factor") (SUSIN, ZAMZAMI e KROEMER, 1998). 


\section{2 - OBJETIVOS}

Esse estudo tem como objetivo principal avaliar por métodos bioquímicos e histopatológicos a eficácia de regimes de fracionamento de dose de luz em Terapia Fotodinâmica utilizando-se de tecido hepático normal de ratos como tecido submetido ao tratamento. Foram avaliados a função mitocondrial dos hepatócitos através da determinação do Estado 3, Estado 4, RCR, ADP/O da respiração mitocondrial, e da determinação do potencial elétrico mitocondrial e da transição da permeabilidade mitocondrial, paralelamente aos dados bioquímicos foram também avaliadas as características da necrose do tecido hepático por microscopia.

Como objetivos secundários esse estudo tem a caracterização do tipo de dano histopatológico nos diferentes regimes de fracionamento de luz, caracterização de um tempo de fracionamento ideal para tecido hepático sadio em ratos e promover sustentação e embasamento teórico para novos estudos de fracionamento de dose de luz em tecido tumoral. 


\section{3 - MATERIAIS E MÉTODOS}

\section{1 - Animais}

Foram utilizados 30 ratos machos, da linhagem Wistar, pesando entre 180 e $200 \mathrm{~g}$, provenientes do Biotério Central da Faculdade de Medicina de Ribeirão Preto - USP. Os animais foram mantidos durante toda a realização do experimento em um alojamento para animais montado no Laboratório de Biofotônica do Instituto de Física São Carlos - USP (figura 9). Esse alojamento reproduz a luz de acordo com o ritmo circadiano, contendo quatro filtros para entrada de ar e um exaustor para saída de ar. Os animais ficaram alojados em gaiolas coletivas de polietileno ( 5 animais por gaiola), contendo tampas metálicas e assoalho forrado com maravalha. Os animais receberam água filtrada e ração comercial específica para roedores livre demanda e a temperatura foi mantida entre 23 a $25{ }^{\circ} \mathrm{C}$.

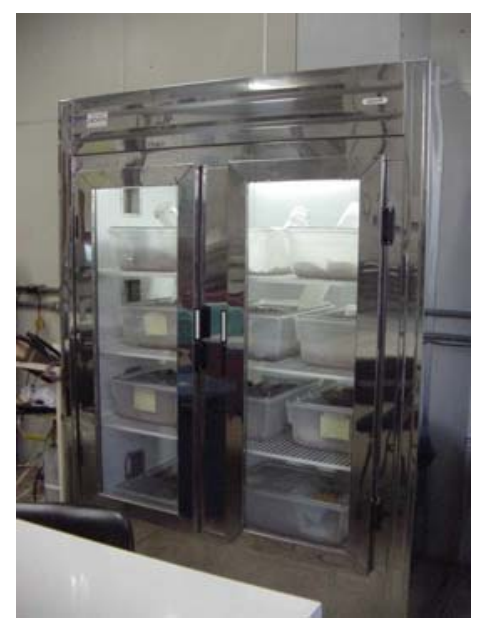

Figura 1 - Alojamento dos animais montado no Laboratório de Biofotônica - Instituto de Física de São Carlos - USP

Apesar da penetração da luz no tecido hepático não ser tão eficiente, o tecido hepático foi escolhido para irradiação por ser de fácil acesso cirúrgico e apresentar características importantes, como ser bem vascularizado para proporcionar boa captação do FS e ser um 
órgão homogêneo em sua estrutura proporcionando menores influências nos resultados da interação da luz com os tecidos irradiados.

\section{2 - Fotossensibilizador}

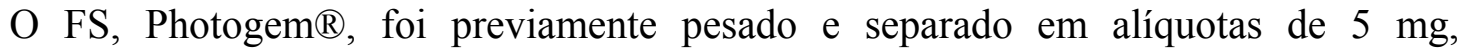
conservadas ao abrigo da luz e mantidas em câmara apropriada à temperatura de $-4{ }^{\circ} \mathrm{C}$. O fármaco separado em alíquotas, antes de utilizado, foi dissolvido em $1 \mathrm{~mL}$ de solução estéril de cloreto de sódio $0,9 \%$, sendo sua concentração final de $5 \mathrm{mg} \mathrm{mL}^{-1}\left(1,32 \mathrm{~mol} \mathrm{~mL}^{-1}\right)$, como orientação do fabricante.

\section{3 - Fonte de Luz}

Para a aplicação neste estudo foi utilizado como fonte de luz, um laser de diodo (Ceralas 630 CeramOptec ${ }^{\circledR}$, Alemanha), que fornece até $2 \mathrm{~W}$ de potência no comprimento de onda de $630 \mathrm{~nm}$, acoplado a uma fibra óptica para iluminação direta da superfície a ser estuda.

\section{4 - Estudo da Necrose Hepática}

\subsection{1 - Fotossensibilização}

O FS, Photogem ${ }^{\circledR}$, foi dissolvido em soro fisiológico $0,9 \%$, na concentração de 5.0 $\mathrm{mg} \mathrm{mL}{ }^{-1}$. Os animais foram fotossensibilizados por injeção endovenosa, pela veia caudal lateral esquerda, na concentração de $1.5 \mathrm{mg}$ para cada quilo de peso animal. 


\subsection{2 - Preparo do Animal}

Foram utilizados 25 animais para realização deste experimento, divididos em 5 grupos e cada grupo continha 5 animais: 800 s, 400s, 200s, 100s e 50s. A tabela IV apresenta a divisão dos grupos experimentais de acordo com os intervalos de fase clara e fase escura.

Os animais foram submetidos a jejum de 12 horas, tendo livre acesso à água. Em seguida foram pesados e anestesiados por injeção intramuscular com solução de Quetamina (Vetanarcol®) na dose de $0.08 \mathrm{~mL} / 100 \mathrm{~g}$ de peso corporal associado ao relaxante muscular, analgésico e sedativo de cloridrato de xilazina $2 \%$ (Coopazine $\left.{ }^{\circledR}\right)$ na dose de $0.04 \mathrm{~mL} / 100 \mathrm{~g}$.

O primeiro grupo (800s) foi submetido a um período ininterrupto de claro de 800 segundos, correspondendo ao grupo de irradiação contínua. O segundo grupo (400s) 3 intervalos alternados de 400 segundos de claro e escuro, o terceiro grupo (200s) submetido a 7 intervalos alternados de 200 segundos de claro e escuro, o quarto grupo (100s) submetido a 15 intervalos alternados de 100 segundos de claro e escuro e o quinto grupo (50s) submetido a 31 intervalos alternados de 50 segundos de claro e escuro.

Tabela I - Divisão dos grupos experimentais $(n=5)$

\begin{tabular}{ccc}
\hline Grupos & $\begin{array}{c}\text { Intervalos de luz } \\
(\mathrm{s})\end{array}$ & $\begin{array}{c}\text { Intervalos } \\
\text { de escuro } \\
(\mathrm{s})\end{array}$ \\
\hline $\mathbf{8 0 0 s}$ & $1 \times 800$ & - \\
$\mathbf{4 0 0 s}$ & $2 \times 400$ & $1 \times 400$ \\
$\mathbf{2 0 0 s}$ & $4 \times 200$ & $3 \times 200$ \\
$\mathbf{1 0 0 s}$ & $8 \times 100$ & $7 \times 100$ \\
$\mathbf{5 0 s}$ & $16 \times 50$ & $15 \times 50$ \\
\hline
\end{tabular}

Após conseguido plano anestésico satisfatório foi realizada uma incisão abdominal mediana longitudinal e o lobo direito do fígado apresentado e isolado fora da cavidade abdominal para garantir as condições de irradiação da estrutura. 


\subsection{3 - Irradiação}

Após o período de 30 minutos da aplicação do FS (Photogem), período no qual por medidas de fluorescência ocorre o valor máximo de concentração do FS no fígado (FERREIRA, 2003), os animais foram iluminados com laser de diodo de $630 \mathrm{~nm}$ (figura 10), com dose total de $200 \mathrm{~J} / \mathrm{cm}^{2}, 800 \mathrm{~mW}$ de potência e com intensidade de $250 \mathrm{~mW} / \mathrm{cm}^{2}$ em uma área de $2 \mathrm{~cm}^{2}$, confirmada com potenciômetro.

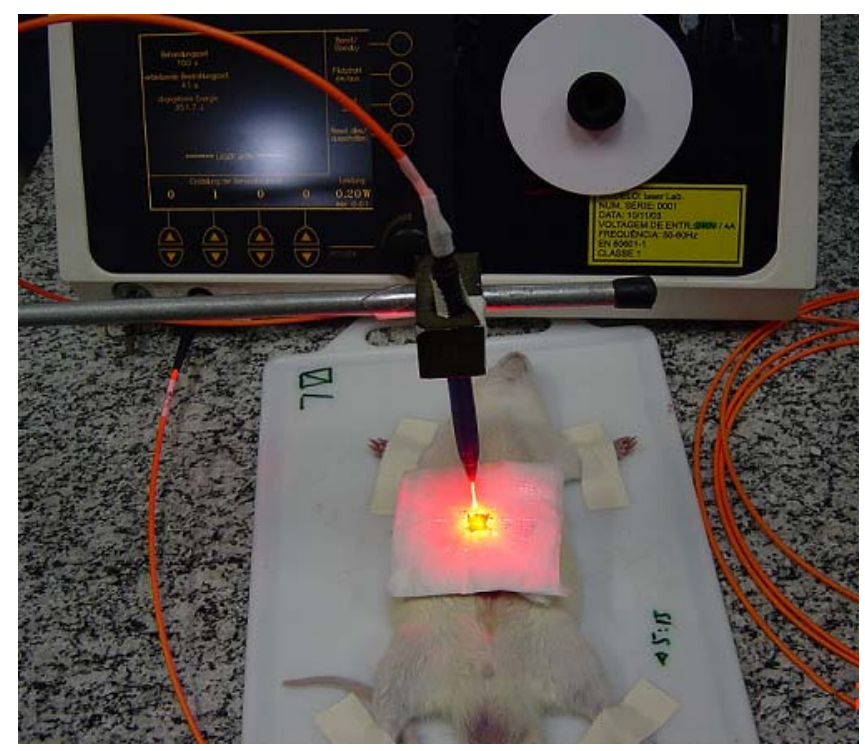

Figura 2 - Irradiação da região do fígado isolada pela máscara de alumínio envolta por gaze

Os grupos foram irradiados em intervalos de tempo iguais, que se alternavam em claro e escuro, iniciando-se sempre com intervalo de claro. No intervalo de claro, promovia-se a irradiação com a luz laser e nos intervalos de escuro, mantinha-se o aparelho desligado e a área irradiada protegida por máscara de alumínio opaca a luz visível.

A área irradiada foi de $2 \mathrm{~cm}$ de diâmetro; para proteção do restante do lobo foi feita uma máscara de papel alumínio envolta por gaze com um orifício de $2 \times 2 \mathrm{~cm}$; esta máscara evitou a iluminação das demais áreas e delimitou a área desejada. Após iluminação, os 
animais foram suturados e recolocados no alojamento com água e ração livre demanda, aguardando por 30 horas a próxima fase de remoção do órgão irradiado.

\subsection{4 - Remoção e Preparo do Material}

Após 30 horas do tratamento, os animais foram induzidos novamente ao plano anestésico cirúrgico e o fígado foi apresentado e o lobo direito do fígado foi removido, em seguida, os animais foram mortos por abertura da cavidade torácica. A área irradiada foi cortada em partes de aproximadamente $1 \mathrm{~mm}$ de espessura com o auxílio de um bisturi. Os cortes foram colocados em frascos plásticos contendo solução tamponada ( $\mathrm{pH}$ 7.4) de formaldeído a 40\% e (Formol - Merck), mantidos assim por 24 horas para fixação do material; após este período, o material é colocado em álcool 70\% para desidratação e posterior preparação das lâminas histológicas.

\subsection{5 - Macroscopia}

$\mathrm{Na}$ abertura da cavidade abdominal e posterior exposição do lobo hepático previamente irradiado, a região do órgão foi observada e fotografada para análise da área necrosada em relação à sua extensão e aspectos macroscópicos.

\subsection{6 - Microscopia}

Para análise microscópica, o material em álcool $70 \%$, foi incluído em bloco de parafina e cortado com $4 \mu \mathrm{m}$ de espessura. Os cortes obtidos foram corados em hematoxilinaeosina (HE), coloração que permite analisar as diferenças morfológicas do tecido alterado em 
relação ao tecido normal, a transição de separação do tecido hepático necrosado e sadio, bem como determinar o tipo de necrose observado e medir a profundidade do tecido necrosado.

Para cada animal, a área necrótica foi examinada em sessões seriadas para medida da profundidade da necrose desde a superfície do tecido hepático. As medidas foram obtidas com uma ocular micrométrica com aumento de 2x, em microscópico Zeiss - RA-18. Para cada corte, foi considerada a maior medida perpendicular à superfície necrótica, que se iniciava na superfície do corte e terminava na transição com o tecido normal.

Para cada um dos animais dos cinco grupos experimentais foram feitas três lâminas e utilizaram-se aquelas que apresentaram os melhores cortes da região necrosada e com colorações histológicas de melhor qualidade. Para calibração da ocular foi utilizada uma lâmina micrométrica própria para esse fim.

3.6 - Isolamento das mitocôndrias

As mitocôndrias foram isoladas por centrifugação diferencial (PEDERSEN et al., 1978). Sob plano anestésico, o lóbo hepático irradiado foi removido e colocado em $50 \mathrm{~mL}$ de meio contendo sacarose 0,25 M, EGTA $1 \mathrm{mM}$ e Hepes-KOH $10 \mathrm{mM}, \mathrm{pH}$ 7,2. O corte foi lavado, picotado e homogeneizado em homogeinizador de tecidos (Potter-Elvehjem) através de três ciclos de 15 segundos com 1 minuto de intervalo. O material homogeneizado foi centrifugado a $770 \mathrm{~g}$ por 5 minutos e o sobrenadante resultante foi centrifugado a $9800 \mathrm{~g}$ por 10 minutos.

O sedimento obtido foi suspenso em $10 \mathrm{~mL}$ de meio contendo sacarose $250 \mathrm{mM}$, EGTA 0,3 mM e HEPES-KOH $10 \mathrm{mM}, \mathrm{pH} 7,2$, e então centrifugado a $4500 \mathrm{~g}$ por 15 minutos. O sedimento final, contendo as mitocôndrias isoladas, foi suspenso em $1 \mathrm{~mL}$ de meio contendo sacarose 0,25 M e HEPES-KOH, pH 7,2 e utilizado durante um período máximo de 3 horas. Todas as etapas de isolamento das mitocôndrias foram conduzidas a $4{ }^{\circ} \mathrm{C}$. 
A proteína mitocondrial foi determinada utilizando-se o médodo de biureto (LUBRAN, 1978) com a utilização da albumina de soro bovino como padrão.

\subsection{1 - Determinação da Respiração mitocondrial}

O consumo de oxigênio foi analisado polarograficamente a $30{ }^{\circ} \mathrm{C}$. Em um sistema polarográfico há um transdutor que corresponde a um eletrodo de oxigênio tipo Clarck (Gilson Medical Electronics, Middlenton, WI, EUA), um aparato de acoplamento e processamento caracterizado por um oxígrafo e um aparato de transcrição de dados representado por um programa de aquisição de dados em computador.

$\mathrm{O}$ oxígrafo foi calibrado com ditionito de sódio, como redutor do $\mathrm{O}_{2}$ total presente no meio de incubação. Foi elaborado um novo sistema de aquisição para o equipamento em substituição ao potenciômetro mecânico usado no equipamento convencional pelo IFSC-USP. Esse novo sistema consiste de um programa instalado em um computador que foi acoplado e recebeu os dados do eletrodo conectado à câmara de análise. O processamento dos dados ocorreu da forma convencional e a inclinação das curvas para cada estado da respiração foi analisada.

O processo consiste em adicionar à câmara de análise $1,3 \mathrm{~mL}$ de meio de respiração (sacarose $125 \mathrm{mM}, \mathrm{KCl} 65 \mathrm{mM}, \mathrm{MgCl}_{2} 1 \mathrm{mM}, \mathrm{KH}_{2} \mathrm{PO}_{4} 2 \mathrm{mM}$, EGTA 0,1 mM e Hepes-KOH 10mM, pH 7,4), $5 \mathrm{mM}$ de meio de substrato de respiração, $2 \mathrm{mg}$ de proteína mitocondrial e durante o procedimento de aquisição dos dados, duas adições de 200 mM de ADP.

Para avaliação da taxa de controle respiratório mitocondrial e a relação ADP/O, o meio utilizado como substrato foi composto de $5 \mathrm{mM}$ de glutamato, piruvato, alfacetoglutarato e malato. A taxa de respiração no Estado 3 conseguida a partir do Estado 4 foi induzida com 400 nmol MgADP divididos em duas adições iguais. As taxas são expressas em número de átomos de oxigênio/minuto/mg de proteína mitocondrial. 
A taxa de controle respiratório foi calculada dividindo o Estado 3 pelo Estado 4 da respiração mitocondrial de acordo com Estabrook (1967)(ESTABROOK, 1967). A taxa ADP/O foi calculada dividindo a quantidade total de ADP adicionada pela quantidade total de oxigênio consumido durante o Estado 3 da respiração mitocondrial (CHANCE e WILLIAMS, 1955).

4.6.1.2 -Determinação do potencial elétrico da membrana mitocondrial interna

O potencial elétrico de membrana das mitocôndrias (PM) foi determinado espectrofluorimetricamente utilizando $5 \mu \mathrm{M}$ de safranina $\mathrm{O}$ como indicador, em fluorímetro tipo SLM-AMINCO sendo que o comprimento de onda de excitação foi $495 \mathrm{~nm}$ e $586 \mathrm{~nm}$ para emissão (FULCERI et al., 1991). As mitocôndrias foram preparadas em meio contendo sacarose $200 \mathrm{mM}$, fosfato de potássio $2 \mathrm{mM}$, EGTA $0,03 \mathrm{mM}$, cloreto de magnésio $1 \mathrm{mM}$ e Hepes-KOH 10 mM, em pH 7,2, sendo o potencial de membrana gerado pela adição de succinato $5 \mathrm{mM}$ e Rotenona $4 \mu \mathrm{M}$ (inibidor do transporte mitocondrial de elétrons). Após a estabilização do potencial de membrana, adicionou-se $1 \mu \mathrm{M}$ do desacoplador FCCP ( $\rho$ trifluorometoxi carbonil cianeto fenilhidrazona). Os resultados obtidos (unidade relativa de fluorescência) foram convertidos em $\mathrm{mV}$, a partir de curva de calibração. Todos os reagentes usados nessa fase dos experimentos foram adquiridos da Sigma ou Merck.

\subsubsection{3 - Transição de Permeabilidade Mitocondrial}

O intumescimento osmótico mitocondrial foi determinado pela diminuição da absorbância das mitocôndrias a $540 \mathrm{~nm}$ em um espectrofotômetro Beckman DU-640. O ensaio é realizado a $30{ }^{\circ} \mathrm{C}$, em $1,5 \mathrm{~mL}$ de meio contendo sacarose $125 \mathrm{mM}, \mathrm{KCl} 65 \mathrm{mM}$, Hepes-KOH pH 7,2 $10 \mathrm{mM}$, Succinato $5 \mathrm{mM}$, Rotenona $5 \mu \mathrm{M}$ e proteína mitocondrial 
0,4mg/mL, sendo o intumescimento induzido por $\mathrm{CaCl}_{2} 20 \mu \mathrm{M}$ e $\mathrm{KH}_{2} \mathrm{PO}_{4} 1 \mathrm{mM}$ (GUNTER e PFEIFFER, 1990; KOWALTOWSKI, CASTILHO e VERCESI, 1996).

\section{7 - Análise estastística}

Para a análise estatística foi utilizado o teste de análise de variância (ANOVA oneway). Os cálculos foram feitos por meio do programa para computador Origin 7.5. Os valores foram considerados significantes quando $\mathrm{P}<0,05$. Os valores são apresentados como média \pm desvio padrão. 


\section{4 - RESULTADOS E DISCUSSÕES}

\section{1 - Macroscopia e microscopia}

Macroscopicamente as características de todos os grupos, com exceção do grupo controle, apresentaram-se de forma muito semelhante. Sendo evidenciado, na área delimitada para irradiação, uma região pálida, de coloração nacarada e formação de aderências com a parede abdominal do animal.

Microscopicamente, na quantificação do processo inflamatório, na qualidade e características da necrose coagulativa, bem como a presença de uma borda bem marcada entre o tecido sadio e o tecido necrosado as lâminas dos grupos de irradiação apresentaram características semelhantes. A única diferença significativa dos parâmetros avaliados foi a diferença nas medidas de profundidade de necrose entre os grupos.

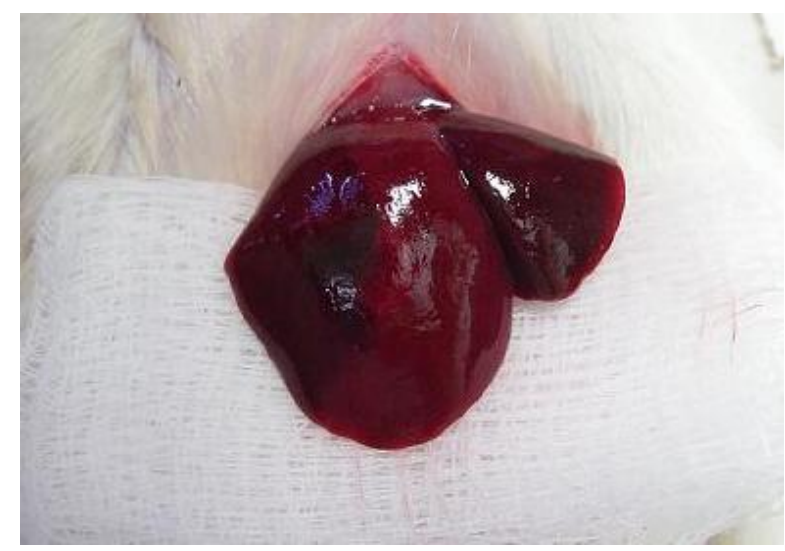

Figura 1 - Detalhe da região do lobo direito do fígado imediatamente após a irradiação

Esses resultados sugerem que mesmo com o fracionamento aumentando a profundidade da necrose no tecido, a morte celular induzida pelo processo fotodinâmico não acontece de forma mais intensa nas células mais superficiais, provavelmente porque o dano celular limita-se às mitocôndrias e por processo “on-off”, isto é, se o processo fotodinâmico 
induzir dano oxidativo suficiente para o limiar oxidativo vital da célula ser ultraopassado ocorrerá a iniciação do eventos que culminarão com a morte celular, independentemente se o dano fotodinâmico continuar ou cessar. Caso esse limiar oxidativo vital não seja atingido a célula se recupera, justificando assim a formação da borda bem definida de tecido necrosado e sadio.

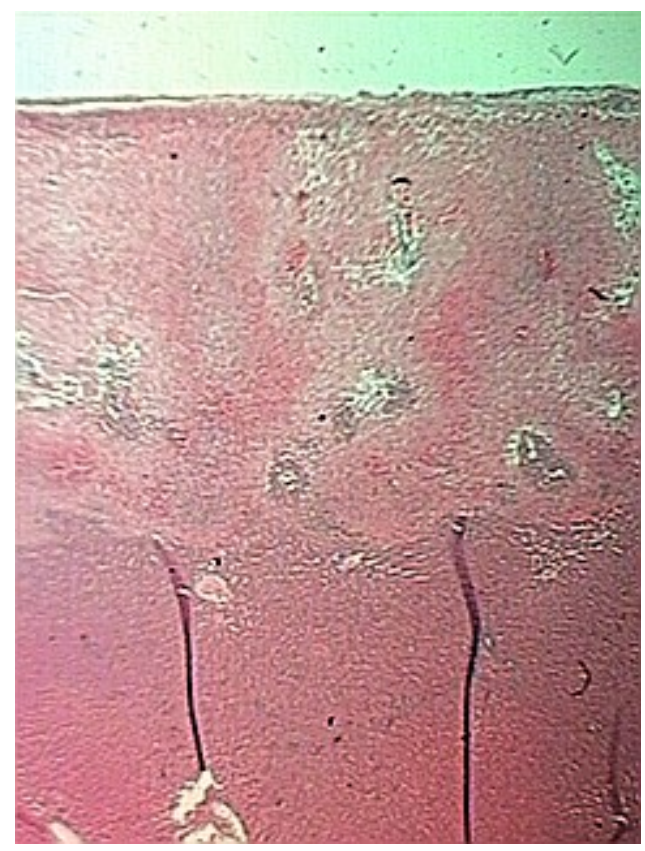

Figura 2 - Corte histológico da região irradiada do fígado corado em Hematoxilina-eosina (aumento de 100x). Visualizado região necrosada na parte superior da figura.

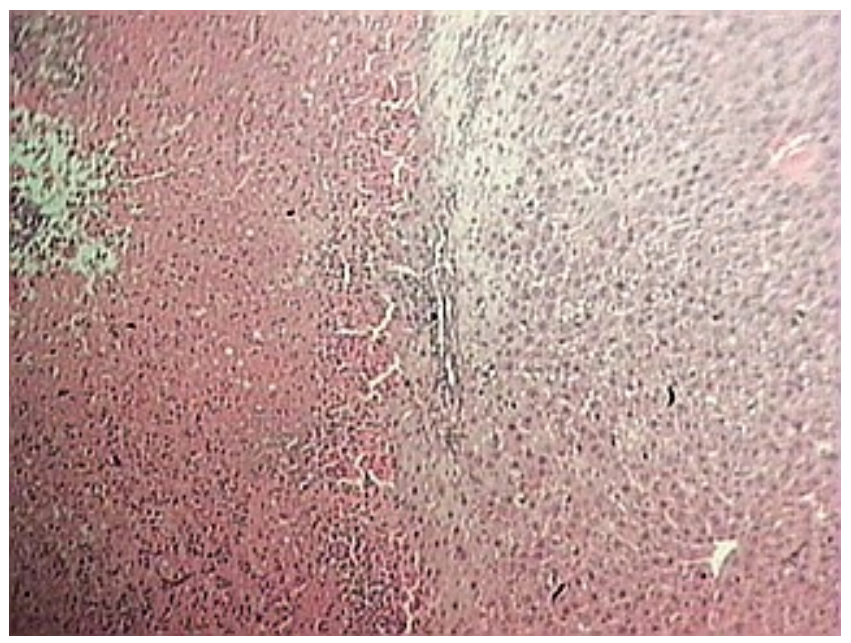

Figura 3 - Corte histológico de fígado após irradiação corado em Hematoxilina-eosina, detalhe da transição do tecido normal (esquerda) e necrosado (direita) (aumento de 400x) 
4.2 - Profundidade de necrose

Na figura 15 são apresentadas as profundidades de necrose nos diversos grupos de fracionamento em que há uma tendência de aumento da profundidade de necrose no tecido em razão da diminuição do tempo de escuro.

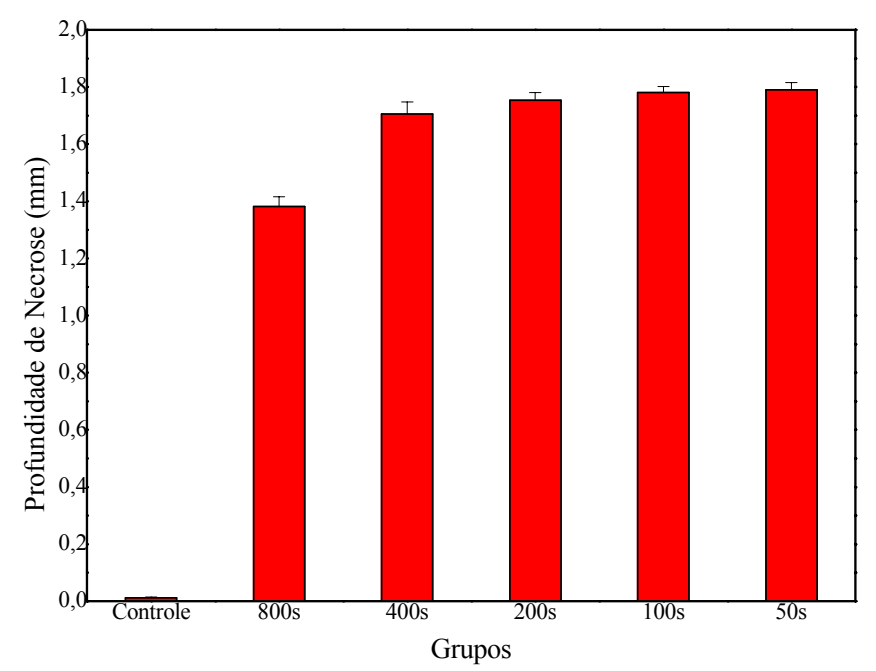

Figura 4 - Profundidade de necrose em função dos intervalos de claro/escuro nos diversos grupos de regimes de luz $(\mathrm{n}=5)$

Entre os grupos 400s, 200s, 100s e 50s não houve diferença significativa $(\mathrm{p}<0,05)$, mas o grupo 800s é significativamente diferente $(\mathrm{p}<0,05)$ de todos os outros grupos. O grupo 400 s apresentou um aumento de $24 \%$ na profundidade de necrose em relação ao grupo 800 s. O grupo controle não apresentou necrose. Os valores de necrose nos diferentes grupos são apresentados na tabela $\mathrm{V}$.

Devido a penetração da luz nos tecidos ser limitada em determinados comprimentos de onda e decrescida sua potência em função da profundidade nos tecidos, era de se esperar a ocorrência de um limite na profundidade de necrose no tecido, uma vez que abaixo dos 
tecidos em que é encontrado o limiar oxidativo vital das células ("threshold") a baixa potência é incapaz de gerar intensidade luminosa suficiente para que a ativação do FS e conseqüente produção de EROs e oxigênio singleto necessários para produção de dano oxidativo celular.

Tabela I - Profundidade de necrose hepática nos grupos com diferentes intervalos de regime de luz (n $=5)$

\begin{tabular}{crl}
\hline Grupo & Profundidade de Necrose $(\mathbf{m m})$ \\
\hline Controle & 0 & \pm \\
$\mathbf{8 0 0 s}$ & $1,38 \quad \pm 0,03$ \\
$\mathbf{4 0 0 s}$ & $1,71 \quad \pm 0,04$ \\
$\mathbf{2 0 0 s}$ & $1,75 \quad \pm 0,03$ \\
$\mathbf{1 0 0 s}$ & $1,78 \quad \pm 0,02$ \\
$\mathbf{5 0 s}$ & $1,79 \pm 0,03$ \\
\hline
\end{tabular}

O fato dessas células não atingirem limiar oxidativo vital em aplicações contínua da luz e virem a morrer em aplicações fracionadas sugere a possibilidade do fracionamento de dose de luz servir como uma técnica resgate, permitindo maior eficácia da técnica nesses regimes, uma vez que o estresse oxidativo que ultrapassa o limiar vital da célula acontece em extratos mais profundos dos tecidos irradiados.

\section{3 - Respiração Mitocondrial}

Na Tabela VI são apresentados os dados referentes à respiração mitocondrial Estado 3 (E3), Estado 4 (E4), RCR e ADP/O) nos diversos grupos de fracionamento. Todos os grupos de dados apresentaram tendências específicas em função da diminuição do tempo de escuro que podem ser mais bem visualizadas em gráficos. 
Tabela II - Dados referentes a respiração mitocondrial nos diferentes regimes de fracionamento de luz $(\mathrm{n}=5)$

\begin{tabular}{ccccc}
\hline Grupo & Estado 3 & Estado 4 & RCR & ADP/O \\
\hline Controle & $129 \pm 11$ & $30 \pm 3$ & $4,4 \pm 0,3$ & $1,44 \pm 0,04$ \\
$\mathbf{8 0 0 s}$ & $120 \pm 5$ & $37 \pm 1$ & $3,4 \pm 0,3$ & $1,28 \pm 0,08$ \\
$\mathbf{4 0 0 s}$ & $98 \pm 8$ & $37 \pm 4$ & $2,5 \pm 0,4$ & $1,15 \pm 0,11$ \\
$\mathbf{2 0 0 s}$ & $82 \pm 7$ & $40 \pm 3$ & $1,9 \pm 0,2$ & $1,01 \pm 0,04$ \\
$\mathbf{1 0 0 s}$ & $92 \pm 9$ & $41 \pm 3$ & $1,9 \pm 0,1$ & $1,02 \pm 0,07$ \\
$\mathbf{5 0 s}$ & $102 \pm 8$ & $41 \pm 2$ & $2,2 \pm 0,2$ & $0,99 \pm 0,08$ \\
& & & & \\
\hline
\end{tabular}

Nos resultados do E3 da respiração mitocondrial encontramos uma tendência de diminuição do consumo de oxigênio nos grupos de fracionamento até 200 segundos e a partir de fracionamentos menores essa tendência inverteu-se graficamente (figura 16).

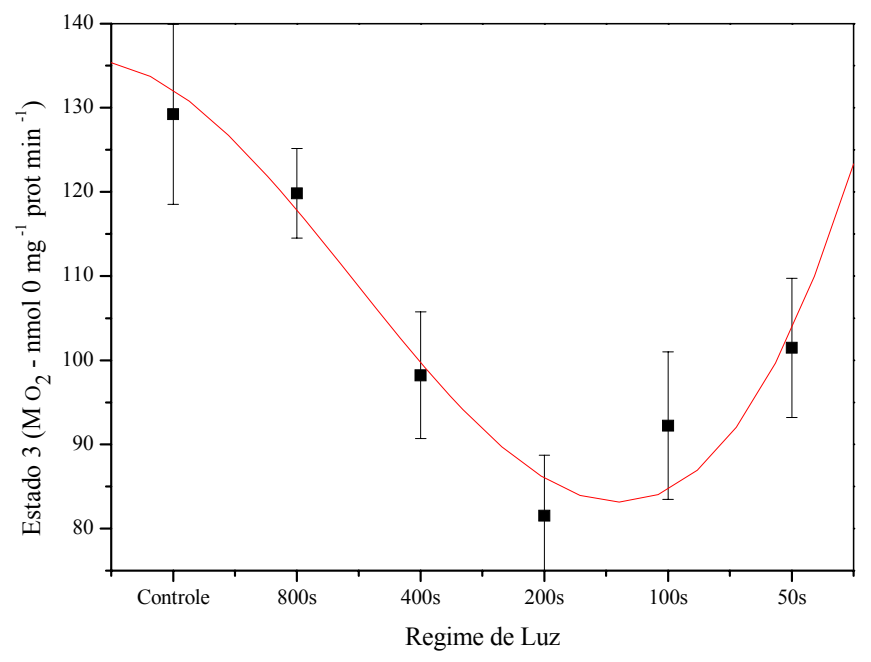

Figura 5 - Consumo de oxigênio no estado 3 da respiração mitocondrial em função de regimes de fracionamento de luz nos diferentes intervalos de escuro 
Nos resultados de estado 4 encontramos uma tendência de aumento dos valores, com diminuição do ritmo do aumento nos regimes de fracionamento com intervalos de escuro mais curtos (figura 17).

Nos resultados da razão de controle respiratório (RCR) encontramos uma tendência de diminuição dos valores de RCR em função da diminuição dos valores de intervalo de escuro até valores de 200 segundos. A partir daí, intervalos menores mostraram uma tendência de aumento de seus valores (figura 18).

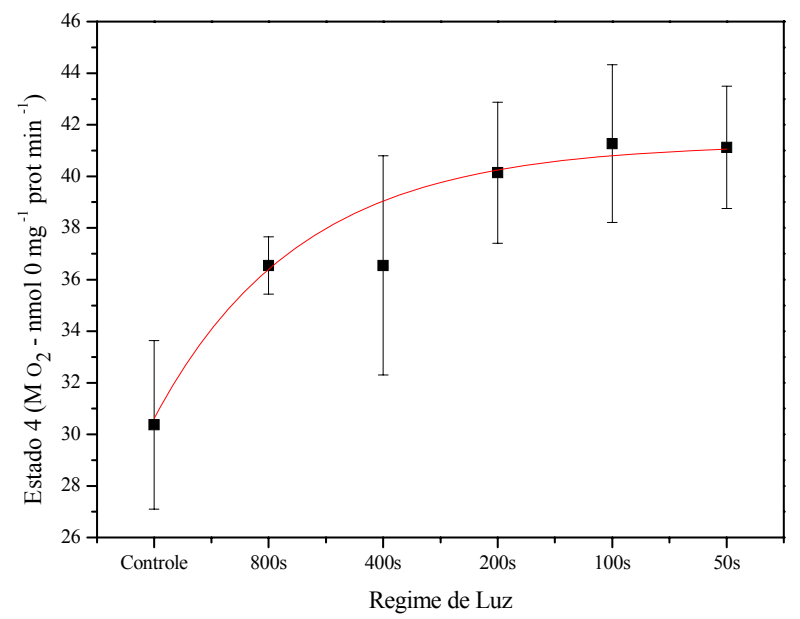

Figura 6 - Consumo de oxigênio no E4 da respiração mitocondrial em função de regimes de fracionamento de luz nos diferentes intervalos de escuro

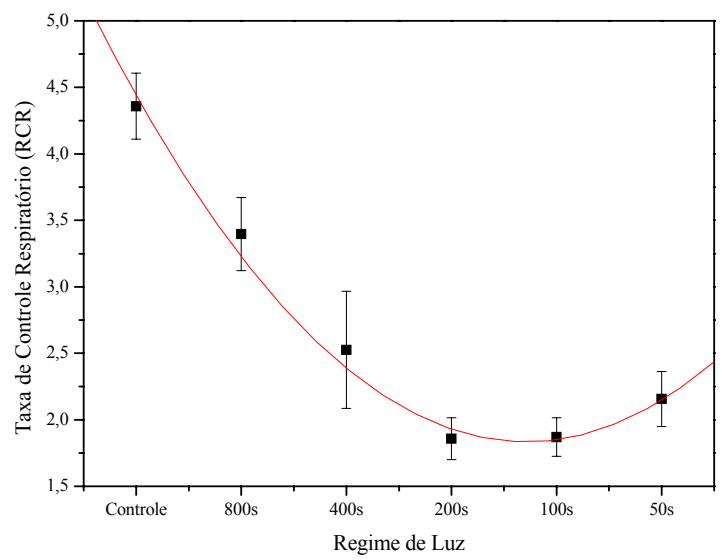

Figura 7 - Taxa de controle de respiração mitocondrial (RCR) em função de regimes de fracionamento de luz nos diferentes intervalos de escuro. 
Nos resultados da razão de $\mathrm{ADP} / \mathrm{O}$ encontramos uma tendência à diminuição dos valores da razão em relação à diminuição do tempo de escuro.Como características dessa diminuição temos uma queda mais acentuada até o regime de fracionamento em $200 \mathrm{~s}$ e uma tendência a estabilização da queda em grupos de fracionamento com intervalo de escuro mais curto como os grupos 100 s e 50 s (figura 19).

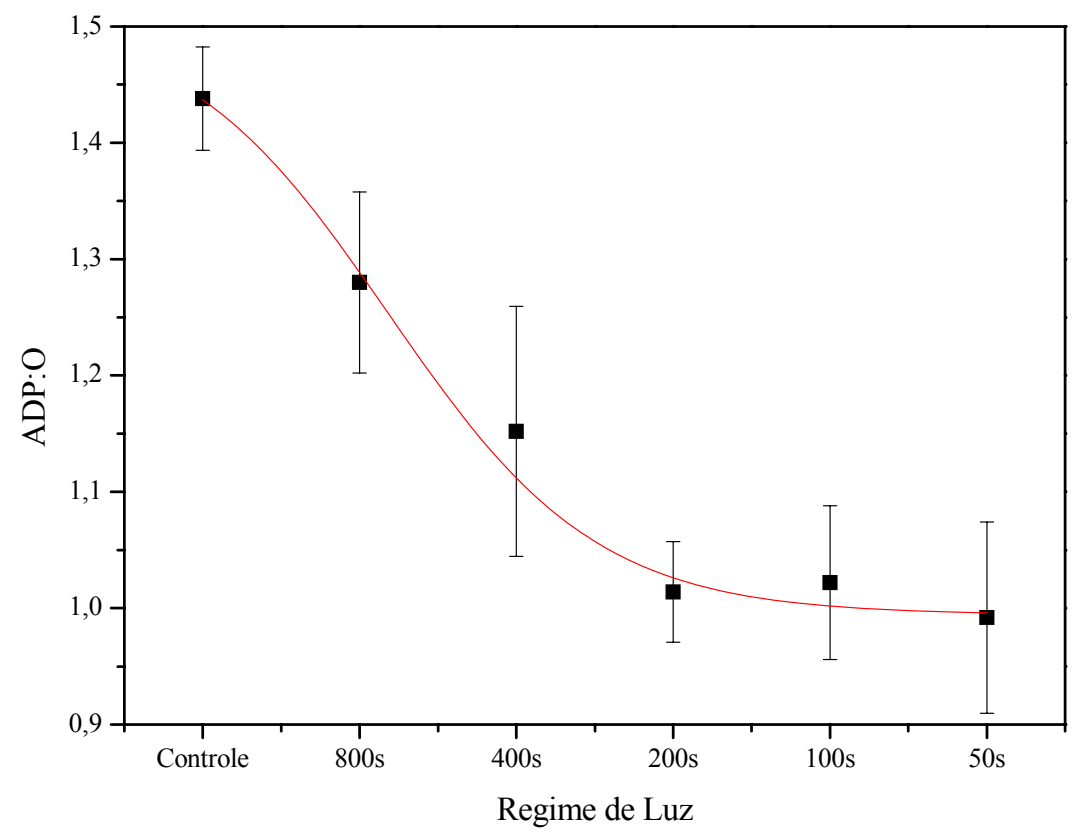

Figura 8 - Taxa de ADP/O da respiração mitocondrial em função de regimes de fracionamento de luz nos diferentes intervalos de escuro

A energia de qualquer substrato utilizado pela mitocôndria é levada para a cadeia transportadora de elétrons nas formas reduzidas dos nucleotídeos NAD ou FAD. O transporte de elétrons e de energia livre segue e são utilizados pelo complexo IV para reduzir oxigênio. Experimentalmente, a diminuição do oxigênio total dissolvido bem como a redução do oxigênio à água podem ser usados para medir a taxa de transporte de elétrons. A redução do oxigênio significa a remoção de elétrons livres do sistema, dessa forma os carreadores do 
sistema podem ser reoxidados, dando continuidade ao sistema de transporte de elétrons e armazenamento da energia livre.

Com a formação e o aumento do gradiente eletroquímico no espaço intermembranas durante o estado de repouso o transporte de elétrons deveria parar, assim como o consumo de oxigênio, mas não é isso que é observado in vitro. Toda preparação de mitocôndrias inclui algumas mitocôndrias que não conseguem manter seu gradiente eletroquímico, por exemplo, por lesão grave nas membranas interna ou externa, pois na presença de substrato a taxa de transporte de elétrons seria máxima (desacoplamento), então parte do consumo de oxigênio no E4 das mitocôndrias isoladas deve-se às mitocôndrias desacopladas por dano durante a preparação do material. Assim, o E4 da respiração mitocondrial é definido como o consumo de oxigênio por mitocôndrias isoladas em um determinado substrato na ausência de ADP ou qualquer outro inibidor metabólico.

Os valores de E4 encontrados tendem a aumentar conforme os intervalos de claro/escuro diminuía, valores esses que mostram que as mitocôndrias estavam consumindo mais oxigênio no estado de repouso em relação aos grupos com tempo de fracionamento maior e ao controle, sugerindo maior número de mitocôndrias danificadas.

O E3 da respiração mitocondrial é definido como o consumo de oxigênio pela respiração mitocondrial quando estimulada por ADP. Quando colocado ADP junto a mitocôndrias no E4, este se liga ao complexo ATP-sintase e na presença de fosfato inorgânico que também irá ligar-se ao complexo, promovem a abertura do canal que permite a passagem dos prótons para a matriz mitocondrial, a energia liberada pela passagem dos prótons é utilizada na produção de ATP. Esse fato promove diminuição do gradiente eletroquímico e conseqüente elevação da velocidade no sistema de transporte de elétrons. Após o uso de todo ADP, o consumo de oxigênio pela respiração mitocondrial retorna ao E4, este pode ser maior do que o E4 anterior pelo próprio efeito desacoplador do ADP. 
No estado ativado, ou E3, as mitocôndrias apresentaram menor consumo de oxigênio com o fracionamento até períodos de escuro de 200s. Nos períodos menores (100s e 50s) houve uma tendência não significativa de aumento dos valores de E3. Esses resultados sugerem que a partir do momento em que o tempo de escuro torna-se curto demais a ponto de ser insuficiente para a reoxigenação celular a níveis satisfatórios, o período subseqüente de luz iniciar-se-á com presença de oxigênio mas que se depletará antes de seu final, uma vez que a célula não estará saturada com oxigênio e o consumo desse pela reação fotodinâmica faz-se de maneira mais rápida do que a reoxigenação tecidual.

Valores baixos de RCR, comparados aos respectivos controles, indicam alterações em um ou mais componentes da cadeia respiratória e, portanto, do estado energético celular, corroborando com a idéia de aumento de dano com o fracionamento de luz (LEHNINGER, NELSON e COX, 2000).

4.4 - Potenciais de membrana e intumescimento mitocondrial

Na Tabela VII são apresentados os dados com respectivos erros de potencial de membrana (PM) e de intumescimento mitocondrial (SW).

Tabela III - Potencial de membrana (PM) e variação do intumescimento mitocondrial $(\Delta \mathrm{SW})$ nos diversos grupos de fracionamento de luz

\begin{tabular}{cccc}
\hline Grupo & $\begin{array}{c}\text { PM (unidade relativa } \\
\text { de fluorescência) }\end{array}$ & $\begin{array}{c}\Delta \text { SW (variação de } \\
\text { absorbância) }\end{array}$ \\
\hline Controle & $0,76 \pm 0,03$ & $0,15 \pm 0,01$ \\
$\mathbf{8 0 0 s}$ & $0,77 \pm 0,02$ & $0,13 \pm 0,01$ \\
$\mathbf{4 0 0 s}$ & $0,79 \pm 0,03$ & $0,13 \pm 0,02$ \\
$\mathbf{2 0 0 s}$ & $0,77 \pm 0,03$ & $0,13 \pm 0,03$ \\
$\mathbf{1 0 0 s}$ & $0,76 \pm 0,02$ & $0,14 \pm 0,01$ \\
$\mathbf{5 0 s}$ & $0,78 \pm 0,02$ & $0,13 \pm 0,01$ \\
\hline
\end{tabular}




\subsection{1 - Potencial elétrico de membrana $(\Delta \Psi)$}

Os resultados do presente estudo não mostraram alterações no potencial de membrana celular das mitocôndrias, fato que pode ser explicado pela capacidade de manutenção do $\Delta \Psi$ estar preservada, apesar dos danos observados nos parâmetros de respiração mitocondrial (figura 20).

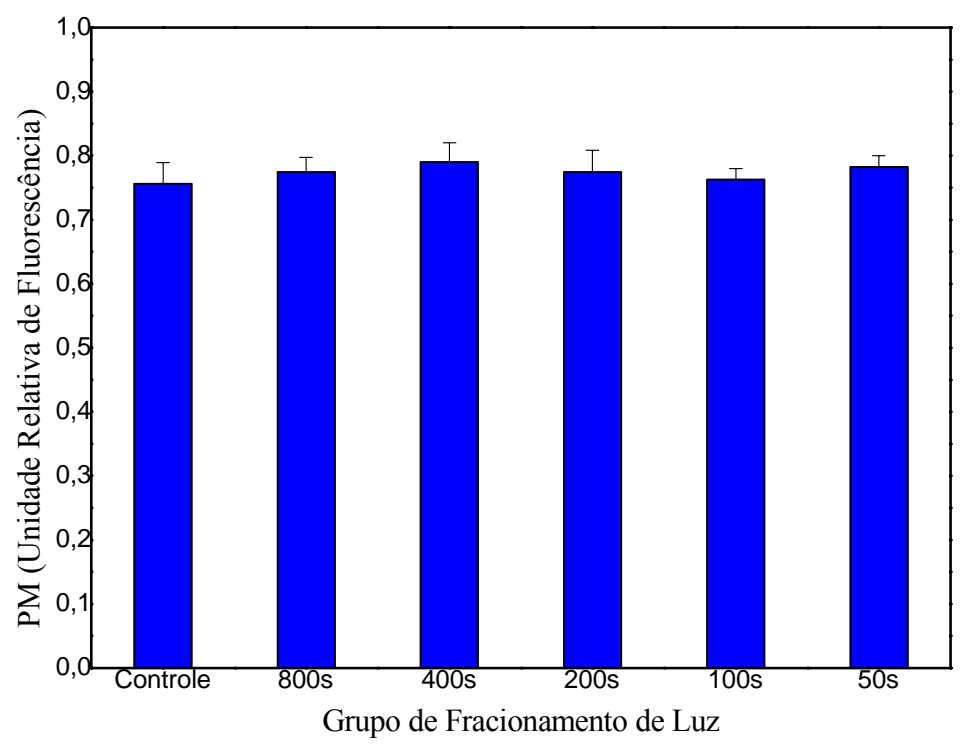

Figura 9 - Potencial de membrana em unidade relativa de fluorescência nos diversos regimes de iluminação

\subsection{2 - Intumescimento osmótico}

Os resultados do presente estudo não mostraram diferença significativa do intumescimento osmótico entre os grupos analisados (figura 21), resultado que corrobora com o resultado de manutenção do potencial elétrico da membrana celular e com a explicação da capacidade de manutenção do $\Delta \Psi$ estar preservada. Apesar dos danos observados nos parâmetros de respiração mitocondrial, o potencial de membrana e intumescimento 
mitocondrial sugerem que o dano causado pela Terapia Fotodinâmica não é causado à membrana mitocondrial ou ainda o dano oxidativo à essa estrutura nessas condições do experimento não tenha ocorrido de forma importante e/ou irreversível.

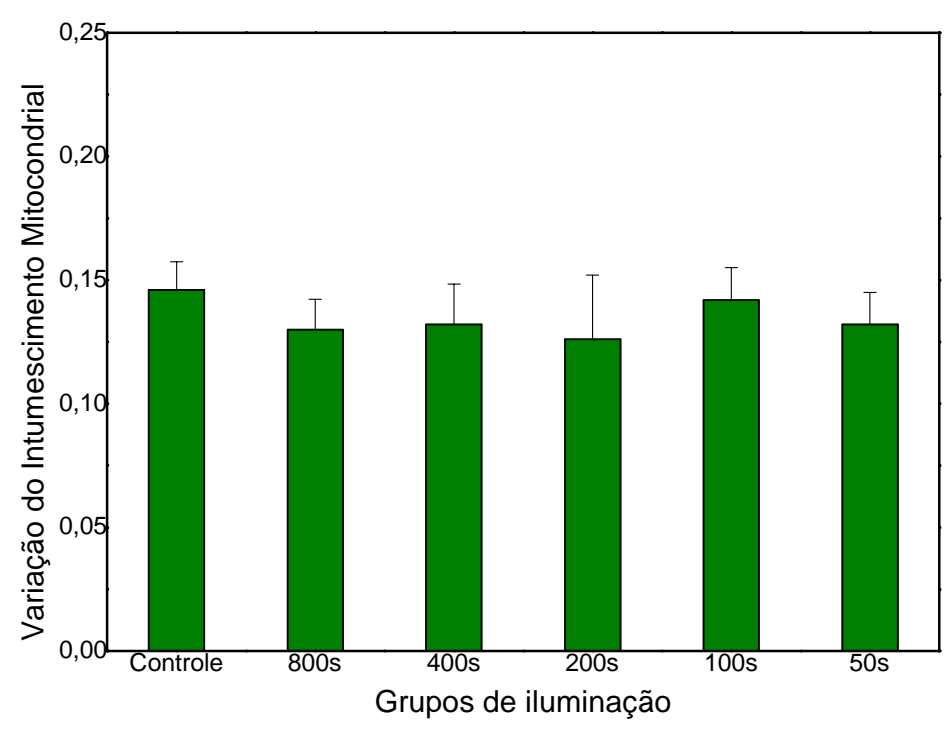

Figura 10- Variação do intumescimento osmótico mitocondrial nos diversos grupos de iluminação

Com o aumento estatisticamente significativo da profundidade de necrose nos grupos 800 s e 400 s a sugestão de resgate de tecidos que estavam abaixo do limiar oxidativo vital da célula torna-se válido e devem ser considerados novos trabalhos para validar o fracionamento de dose de energia em protocolos de aplicação clínica. 


\section{5 - CONCLUSÕES}

A proposta de correlacionar profundidade de necrose e bioquímica celular para avaliação da eficácia do fracionamento de dose de luz em Terapia Fotodinâmia foi realizada através da caracterização da função mitocondrial, organela-alvo mais importante na indução dos tecidos à morte.

Os parâmetros utilizados para avaliar quantitativamente o dano mitocondrial induzido pela Terapia Fotodinâmica foram o Estado 3, o Estado 4, o RCR e o ADP/O. O aumento da profundidade de necrose no tecido hepático de ratos em função do fracionamento da dose de luz e da diminuição do tempo de escuro corrobora com os dados obtidos pelo estudo bioquímico mitocondrial.

Com os resultados obtidos nesse trabalho, percebe-se a variabilidade nas respostas obtidas nos diversos grupos alterando apenas o tempo de escuro, apesar dessa variabilidade, esses resultados seguem um caminho lógico em função da variação do tempo de fracionamento.

O fundamento do fracionamento de dose de luz é propiciar a produção continuada de espécies reativas de oxigênio e oxigênio singleto nos tecidos tratados por terapia fotodinâmica através da maior disponibilidade de oxigênio em sua forma molecular no meio intracelular, por permitir a reoxigenação tecidual durante os períodos de escuro. A partir do período necessário para que os tecidos atinjam a pressão parcial de oxigênio máxima dentro do intervalo de escuro, a continuidade desse período sem luz não mais se justifica.

Os resultados desse estudo mostraram que o dano mitocondrial máximo é alcançado com irradiação fracionada e intervalo de escuro entre 100 e 200 segundos, sugerindo que esse é o tempo necessário para o oxigênio difundir-se dos capilares até as células e chegar 
a concentrações ideais para iniciar um novo ciclo de claro com o máximo de dano pela ação fotodinâmica. Dado esse que difere da literatura que sugere o tempo ideal para alcançar a pressão parcial de oxigênio máxima dentro da célula seja entre 60 e 100 segundos, provavelmente pela vasoconstrição e alterações vasculares provocadas pela própria ação fotodinâmica que dificultariam sua difusão.

Diversos estudos utilizam-se de tempos de fracionamento de dose de luz bastante diferentes, por vezes ainda variando a dose total de luz entregue aos tecidos e a partir desses resultados sugerem conclusões díspares e inconclusivas.

Os resultados mostraram um aumento de $30 \%$ na profundidade de necrose nos períodos fracionados em relação ao grupo de em que se tinham períodos de aplicação contínua de luz em fígado de ratos tratados com Photogem ${ }^{\circledR}$. A partir dos dados obtidos nesse trabalho pode-se concluir que o fracionamento de dose de luz aumenta a eficácia do processo fotodinâmico quando são avaliados os danos relacionados à profundidade de necrose e às mitocôndrias, alvo principal da ação fotodinâmica.

Foi demonstrado ainda, que o fracionamento da dose de luz leva um maior número de células à morte com a mesma quantidade de energia e de fármaco sensibilizador, uma vez que a extensão da faixa de necrose aumenta apesar de manter suas características histológicas em todos os grupos. Uma parte das células do tecido em tratamento que permaneciam abaixo do limiar oxidativo vital da célula em aplicações contínuas de luz e que dessa forma não eram induzidas à morte, pode ser resgatada em aplicações fracionadas de dose de luz.

O conceito de resgate pela técnica de fracionamento de dose de luz refere-se aos extratos celulares que tiveram seu dano oxidativo cessado nas aplicações contínuas por falta de oxigênio molecular intracelular, mas que em regimes de aplicação fracionada 
conseguem converter a fração de energia luminosa em dano oxidativo a cada ciclo do fracionamento. Essas frações de danos oxidativo somadas proporcionam o alcance do limiar oxidativo da célula induzindo-a a morte, diferentemente de aplicações contínuas em que o dano é obtido de uma vez, até ser interrompido pela hipóxia celular.

Uma vez que a disponibilidade de oxigênio molecular nas células-alvo é de importância fundamental para a ocorrência do dano oxidativo acima do limiar vital da célula, a idéia de fracionamento de dose de luz em terapia fotodinâmica deve ser considerada e estudos adicionais envolvendo tecidos tumorais são necessários. Isso significa atenção especial ao desenvolvimento de modelos matemáticos e experimentais relacionados à disponibilidade de oxigênio e seu consumo pela reação fotodinâmica e ao tempo de reoxigenação necessário para saturação intracelular máxima.

O estudo dosimétrico para o ajuste fino dos resultados em Terapia Fotodinâmica fazse fundamental para o desenvolvimento dessa técnica como opção terapêutica para o câncer, fundamentando-a com maior credibilidade e confiança. 


\section{6 - REFERÊNCIAS BIBLIOGRÁFICAS}

ACKROYD, R.; KELTY, C.; BROWN, N.;REED, M. The history of photodetection and photodynamic therapy. Photochem Photobiol, v.74, p.656-69, 2001.

ALBERTS, B.; JOHNSON, A.; LEWIS, J.; RAFF, M.; ROBERTS, K.;WALTER, P. Molecular Biology of the Cell: Garland. 2002. 1616 p.

BALCHUM, O. J.; DOIRON, D. R.;HUTH, G. C. HpD photodynamic therapy for obstructing lung cancer. Prog Clin Biol Res, v.170, p.727-45, 1984.

BATANDIER, C.; LEVERVE, X.;FONTAINE, E. Opening of the mitochondrial permeability transition pore induces reactive oxygen species production at the level of the respiratory chain complex I. J Biol Chem, v.279, p.17197-204, 2004.

BERR, F. Photodynamic therapy for cholangiocarcinoma. Semin Liver Dis, v.24, p.177-87, 2004.

BERTINO, J. R.;HAIT, W. Princípios do tratamento do câncer. In: L. Goldman e D. Ausiello (Ed.). Cecil, tratado de medicina interna. Rio de Janeiro: Elsiever, v.2, 2005. Princípios do tratamento do câncer, p.2927

BONNETT, R. Photosensitizers of the Porphyrin and Phthalocyanine Series for Photodynamic Therapy. Chemical Society Reviews, v.24, p.19-33, 1995.

BONNETT, R.;BERENBAUM, M. C. HPD - a study of its components and their properties. Adv Exp Med Biol, v.160, p.241-50, 1983.

BORLE, F.; RADU, A.; MONNIER, P.; VAN DEN BERGH, H.;WAGNIERES, G. Evaluation of the photosensitizer Tookad for photodynamic therapy on the Syrian golden hamster cheek pouch model: light dose, drug dose and drug-light interval effects. Photochem Photobiol, v.78, p.377-83, 2003.

BOWN, S. G.; ROGOWSKA, A. Z.; WHITELAW, D. E.; LEES, W. R.; LOVAT, L. B.; RIPLEY, P.; JONES, L.; WYLD, P.; GILLAMS, A.;HATFIELD, A. W. Photodynamic therapy for cancer of the pancreas. Gut, v.50, p.549-57, 2002.

BROWN, S. B.; BROWN, E. A.;WALKER, I. The present and future role of photodynamic therapy in cancer treatment. Lancet Oncol, v.5, p.497-508, 2004.

CHANCE, B.;WILLIAMS, G. R. Respiratory enzymes in oxidative phosphorylation. I. Kinetics of oxygen utilization. J Biol Chem, v.217, p.383-93, 1955.

COLUSSI, V. C. Intensificação da terapia fotodinâmica do câncer pela variação da pressão parcial do oxigênio no tecido: efeitos físicos e biológicos. 1997. 100 p.

(Doutorado). Faculdade de Ciências Médicas, Unicamp, Campinas, 1997. 
CUENCA, R. E.; ALLISON, R. R.; SIBATA, C.;DOWNIE, G. H. Breast cancer with chest wall progression: treatment with photodynamic therapy. Ann Surg Oncol, v.11, p.322-7, 2004.

DOHMOTO, M.; HUNERBEIN, M.;SCHLAG, P. M. Palliative endoscopic therapy of rectal carcinoma. Eur J Cancer, v.32A, p.25-9, 1996.

DOLMANS, D. E. J. G. J.; FUKUMURA, D.;JAIN, R. K. Photodynamic therapy for cancer. Nature Reviews Cancer, v.3, p.380-387, 2003.

DOUGHERTY, T. J.; GOMER, C. J.; HENDERSON, B. W.; JORI, G.; KESSEL, D.; KORBELIK, M.; MOAN, J.;PENG, Q. Photodynamic therapy. J Natl Cancer Inst, v.90, p.889-905, 1998.

DOUGHERTY, T. J.; GRINDEY, G. B.; FIEL, R.; WEISHAUPT, K. R.;BOYLE, D. G. Photoradiation therapy. II. Cure of animal tumors with hematoporphyrin and light. J Natl Cancer Inst, v.55, p.115-21, 1975.

DOUGHERTY, T. J.; KAUFMAN, J. E.; GOLDFARB, A.; WEISHAUPT, K. R.; BOYLE, D.;MITTLEMAN, A. Photoradiation therapy for the treatment of malignant tumors. Cancer Res, v.38, p.2628-35, 1978.

ESTABROOK, R. W. Mitochondrial respiratory control and the polarographic measurement of ADP/O ratios. Methods Enzymol, v.10, p.41-57, 1967.

FERREIRA, J. Análise da necrose em tecidos normais fotossensibilizados pós terapia fotodinâmica - estudo in vivo. 2003. 108 p. (Dissertação de mestrado). Departamento de Patologia, Universidade de São Paulo, Ribeirão Preto, 2003.

FINGAR, V. H.;HENDERSON, B. W. Drug and light dose dependence of photodynamic therapy: a study of tumor and normal tissue response. Photochem Photobiol, v.46, p.837-41, 1987.

FOSTER, T. H.; HARTLEY, D. F.; NICHOLS, M. G.;HILF, R. Fluence rate effects in photodynamic therapy of multicell tumor spheroids. Cancer Res, v.53, p.1249-54, 1993.

FOSTER, T. H.; MURANT, R. S.; BRYANT, R. G.; KNOX, R. S.; GIBSON, S. L.;HILF, R. Oxygen consumption and diffusion effects in photodynamic therapy. Radiat Res, v.126, p.296-303, 1991.

FRIEDBERG, J. S.; MICK, R.; STEVENSON, J.; METZ, J.; ZHU, T.; BUYSKE, J.; STERMAN, D. H.; PASS, H. I.; GLATSTEIN, E.;HAHN, S. M. A phase I study of Foscanmediated photodynamic therapy and surgery in patients with mesothelioma. Ann Thorac Surg, v.75, p.952-9, 2003.

FULCERI, R.; BELLOMO, G.; MIRABELLI, F.; GAMBERUCCI, A.;BENEDETTI, A. Measurement of mitochondrial and non-mitochondrial Ca2+ in isolated intact hepatocytes: a critical re-evaluation of the use of mitochondrial inhibitors. Cell Calcium, v.12, p.431-9, 1991. 
GILSON, D.; ASH, D.; DRIVER, I.; FEATHER, J. W.;BROWN, S. Therapeutic ratio of photodynamic therapy in the treatment of superficial tumours of skin and subcutaneous tissues in man. Br J Cancer, v.58, p.665-7, 1988.

GOLD, M. H.;NESTOR, M. S. Current treatments of actinic keratosis. J Drugs Dermatol, v.5, p.17-25, 2006.

GOLLNICK, S. O.; LIU, X.; OWCZARCZAK, B.; MUSSER, D. A.;HENDERSON, B. W. Altered expression of interleukin 6 and interleukin 10 as a result of photodynamic therapy in vivo. Cancer Res, v.57, p.3904-9, 1997.

GOODELL, T. T.;MULLER, P. J. Photodynamic therapy: a novel treatment for primary brain malignancy. J Neurosci Nurs, v.33, p.296-300, 2001.

GROSSWEINER, L. I. PDT light dosimetry revisited. J Photochem Photobiol B, v.38, p.258-68, 1997.

GUNTER, T. E.;PFEIFFER, D. R. Mechanisms by which mitochondria transport calcium. Am J Physiol, v.258, p.C755-86, 1990.

HAYATA, Y.; KATO, H.; KONAKA, C.; ONO, J.;TAKIZAWA, N. Hematoporphyrin derivative and laser photoradiation in the treatment of lung cancer. Chest, v.81, p.269-77, 1982.

HAYATA, Y.; KATO, H.; OKITSU, H.; KAWAGUCHI, M.;KONAKA, C. Photodynamic therapy with hematoporphyrin derivative in cancer of the upper gastrointestinal tract. Semin Surg Oncol, v.1, p.1-11, 1985.

HENDERSON, B. W.;DOUGHERTY, T. J. How does photodynamic therapy work? Photochem Photobiol, v.55, p.145-57, 1992.

HENDERSON, B. W.;FINGAR, V. H. Oxygen limitation of direct tumor cell kill during photodynamic treatment of a murine tumor model. Photochem Photobiol, v.49, p.299-304, 1989.

HILLEMANNS, P.; WANG, X.; STAEHLE, S.; MICHELS, W.;DANNECKER, C.

Evaluation of different treatment modalities for vulvar intraepithelial neoplasia (VIN): $\mathrm{CO}(2)$ laser vaporization, photodynamic therapy, excision and vulvectomy. Gynecol Oncol, v.100, p.271-5, 2006.

HUNTER, D. R.;HAWORTH, R. A. The Ca2+-induced membrane transition in mitochondria. III. Transitional Ca2+ release. Arch Biochem Biophys, v.195, p.468-77, 1979.

IINUMA, S.; SCHOMACKER, K. T.; WAGNIERES, G.; RAJADHYAKSHA, M.;

BAMBERG, M.; MOMMA, T.;HASAN, T. In vivo fluence rate and fractionation effects on tumor response and photobleaching: photodynamic therapy with two photosensitizers in an orthotopic rat tumor model. Cancer Res, v.59, p.6164-70, 1999.

INCA. O Problema do Câncer no Brasil. Ministério da Saúde - Coordenação de programas de controle de câncer. 1997 
. Estimativa 2006: Incidência de câncer no Brasil. Rio de Janeiro: Ministério da Saúde. 2005. 94 p.

KAVARNOS, G. J.;TURRO, N. J. Photosensitization by Reversible Electron-Transfer Theories, Experimental-Evidence, and Examples. Chemical Reviews, v.86, p.401-449, 1986.

KELLY, J. F.;SNELL, M. E. Hematoporphyrin derivative: a possible aid in the diagnosis and therapy of carcinoma of the bladder. J Urol, v.115, p.150-1, 1976.

KELLY, J. F.; SNELL, M. E.;BERENBAUM, M. C. Photodynamic destruction of human bladder carcinoma. Br J Cancer, v.31, p.237-44, 1975.

KESSEL, D.; THOMPSON, P.; MUSSELMAN, B.;CHANG, C. K. Probing the structure and stability of the tumor-localizing derivative of hematoporphyrin by reductive cleavage with LiAlH4. Cancer Res, v.47, p.4642-5, 1987.

KOWALTOWSKI, A. J.; CASTILHO, R. F.;VERCESI, A. E. Opening of the mitochondrial permeability transition pore by uncoupling or inorganic phosphate in the presence of $\mathrm{Ca} 2+$ is dependent on mitochondrial-generated reactive oxygen species. FEBS Lett, v.378, p.150-2, 1996.

KOWALTOWSKI, A. J.;VERCESI, A. E. Mitochondrial damage induced by conditions of oxidative stress. Free Radic Biol Med, v.26, p.463-71, 1999.

KURACHI, C.; MELO, C. A. S.; MARCASSA, L. G.; ZÍLIO, S. C.; BAGNATO, V. S.; CESTARI, G. A.; JAVARONI, A.; BERTO, J. C.; PASSERI, C.; BONILHA, V. S.; SILVA, M.; FERREIRA, J.; VERÍSSIMO, F. M.;SOUZA, C. S. Implantação Clínica da Terapia Fotodinâmica no Brasil: Breve Histórico e Resultados Alcançados. Revista da Sociedade Brasileira de Cancerologia, p.33 - 41, 2002.

LAUSTRIAT, G. Molecular mechanisms of photosensitization. Biochimie, v.68, p.771-8, 1986.

LEHNINGER, A. L.; NELSON, I. L.;COX, M. M. Fosforilação oxidativa e fotofosforilação. In: (Ed.). Princípios de bioquímica. São Paulo: Savier, 2000. Fosforilação oxidativa e fotofosforilação

LOU, P. J.; JAGER, H. R.; JONES, L.; THEODOSSY, T.; BOWN, S. G.;HOPPER, C. Interstitial photodynamic therapy as salvage treatment for recurrent head and neck cancer. $\mathbf{B r}$ J Cancer, v.91, p.441-6, 2004.

LUBRAN, M. M. The measurement of total serum proteins by the Biuret method. Ann Clin Lab Sci, v.8, p.106-10, 1978.

MAZIERE, J. C.; SANTUS, R.; MORLIERE, P.; REYFTMANN, J. P.; CANDIDE, C.; MORA, L.; SALMON, S.; MAZIERE, C.; GATT, S.;DUBERTRET, L. Cellular uptake and photosensitizing properties of anticancer porphyrins in cell membranes and low and high density lipoproteins. J Photochem Photobiol B, v.6, p.61-8, 1990. 
MCCAUGHAN, J. S., JR.; HICKS, W.; LAUFMAN, L.; MAY, E.;ROACH, R. Palliation of esophageal malignancy with photoradiation therapy. Cancer, v.54, p.2905-10, 1984.

MORIWAKI, S. I.; MISAWA, J.; YOSHINARI, Y.; YAMADA, I.; TAKIGAWA, M.;TOKURA, Y. Analysis of photosensitivity in Japanese cancer-bearing patients receiving photodynamic therapy with porfimer sodium (Photofrin). Photodermatol Photoimmunol Photomed, v.17, p.241-3, 2001.

MULLER, S.; WALT, H.; DOBLER-GIRDZIUNAITE, D.; FIEDLER, D.;HALLER, U. Enhanced photodynamic effects using fractionated laser light. J Photochem Photobiol B, v.42, p.67-70, 1998.

NOWIS, D.; MAKOWSKI, M.; STOKLOSA, T.; LEGAT, M.; ISSAT, T.;GOLAB, J. Direct tumor damage mechanisms of photodynamic therapy. Acta Biochim Pol, v.52, p.339-52, 2005.

OBERDANNER, C. B.; PLAETZER, K.; KIESSLICH, T.;KRAMMER, B. Photodynamic treatment with fractionated light decreases production of reactive oxygen species and cytotoxicity in vitro via regeneration of glutathione. Photochem Photobiol, v.81, p.609-13, 2005.

OLEINICK, N. L.; MORRIS, R. L.;BELICHENKO, I. The role of apoptosis in response to photodynamic therapy: what, where, why, and how. Photochem Photobiol Sci, v.1, p.1-21, 2002.

PATTERSON, M. S.;WILSON, B. C. Photodynamic Therapy. In: J. V. Dyh (Ed.). The technology of radiation oncology. Madison: Medical Physics Publishing, 1999.

Photodynamic Therapy, p.941-980

PEDERSEN, P. L.; GREENAWALT, J. W.; REYNAFARJE, B.; HULLIHEN, J.; DECKER, G. L.; SOPER, J. W.;BUSTAMENTE, E. Preparation and characterization of mitochondria and submitochondrial particles of rat liver and liver-derived tissues. Methods Cell Biol, v.20, p.411-81, 1978.

POGUE, B. W.;HASAN, T. A theoretical study of light fractionation and dose-rate effects in photodynamic therapy. Radiat Res, v.147, p.551-9, 1997.

PRIME, J. Les accidentes toxiques par l'eosinate de sodium. Jouve and Boyer, Paris, 1901.

RAAB, O. Uber die Wirkung fluoreszierender Stoffe auf Infusorien. Z. Biol., v.39, p.524546, 1900.

SALOMON, D. [Photodynamic therapy in dermatology, a new therapeutic tool]. Rev Med Suisse, v.1, p.1094-8, 2005.

SAÚDE, R. I. D. I. P. A. Anuário Estatístico de Saúde no Brasil. Ministério da Saúde06 set 2004. 2001

SHARMAN, W. M.; ALLEN, C. M.;VAN LIER, J. E. Photodynamic therapeutics: basic principles and clinical applications. Drug Discov Today, v.4, p.507-517, 1999. 
SIBATA, C. H.; COLUSSI, V. C.; OLEINICK, N. L.;KINSELLA, T. J. Photodynamic therapy: a new concept in medical treatment. Braz J Med Biol Res, v.33, p.869-80, 2000. 2001. Photodynamic therapy in oncology. Expert Opin Pharmacother, v.2, p.917-27,

SUSIN, S. A.; ZAMZAMI, N.;KROEMER, G. Mitochondria as regulators of apoptosis: doubt no more. Biochim Biophys Acta, v.1366, p.151-65, 1998.

TOGASHI, H.; UEHARA, M.; IKEDA, H.;INOKUCHI, T. Fractionated photodynamic therapy for a human oral squamous cell carcinoma xenograft. Oral Oncol, v.42, p.526-32, 2006.

TSUTSUI, H.; MACROBERT, A. J.; CURNOW, A.; ROGOWSKA, A.; BUONACCORSI, G.; KATO, H.;BOWN, S. G. Optimisation of illumination for photodynamic therapy with mTHPC on normal colon and a transplantable tumour in rats. Lasers Med Sci, v.17, p.101-9, 2002.

VAN GEEL, I. P.; OPPELAAR, H.; MARIJNISSEN, J. P.;STEWART, F. A. Influence of fractionation and fluence rate in photodynamic therapy with Photofrin or mTHPC. Radiat Res, v.145, p.602-9, 1996.

VEENHUIZEN, R. B.;STEWART, F. A. The importance of fluence rate in photodynamic therapy: is there a parallel with ionizing radiation dose-rate effects? Radiother Oncol, v.37, p.131-5, 1995.

VERIGOS, K.; STRIPP, D. C.; MICK, R.; ZHU, T. C.; WHITTINGTON, R.; SMITH, D.; DIMOFTE, A.; FINLAY, J.; BUSCH, T. M.; TOCHNER, Z. A.; MALKOWICZ, S.; GLATSTEIN, E.;HAHN, S. M. Updated results of a phase I trial of motexafin lutetiummediated interstitial photodynamic therapy in patients with locally recurrent prostate cancer. $\mathbf{J}$ Environ Pathol Toxicol Oncol, v.25, p.373-88, 2006.

VON TAPPEINER, H.;JESIONEK, A. Therapeutische Versuchen mit fluoreszierenden Stoffen. Muench. Med. Wochenschr, v.47, p.2042-2044, 1903.

VON TAPPEINER, H.;JODLBAUER, A. Uber Wirkung der photodynamischen fluorieszierenden) Stoffe auf Protozoan und Enzyme. Dtsch. Arch. Klin. Med., v.80, p.427487, 1904.

Die Sensibilisierende Wirkung fluorieszierender Substanzer. Gesammte Untersuchungen uber die photodynamische Erscheinung. F. C. W. Vogel, Leipzig., 1907.

WACHTLIN, J.; BECHRAKIS, N. E.;FOERSTER, M. H. [Photodynamic therapy with verteporfin for uveal melanoma]. Ophthalmologe, v.102, p.241-6, 2005.

WILE, A. G.; COFFEY, J.; NAHABEDIAN, M. Y.; BAGHDASSARIAN, R.; MASON, G. R.;BERNS, M. W. Laser photoradiation therapy of cancer: an update of the experience at the University of California, Irvine. Lasers Surg Med, v.4, p.5-12, 1984. 
WILE, A. G.; DAHLMAN, A.; BURNS, R. G.;BERNS, M. W. Laser photoradiation therapy of cancer following hematoporphyrin sensitization. Lasers Surg Med, v.2, p.163-8, 1982.

WILSON, J. J.; JONES, H.; BUROCK, M.; SMITH, D.; FRAKER, D. L.; METZ, J.;

GLATSTEIN, E.;HAHN, S. M. Patterns of recurrence in patients treated with photodynamic therapy for intraperitoneal carcinomatosis and sarcomatosis. Int J Oncol, v.24, p.711-7, 2004.

ZILBERSTEIN, J.; BROMBERG, A.; FRANTZ, A.; ROSENBACH-BELKIN, V.; KRITZMANN, A.; PFEFERMANN, R.; SALOMON, Y.;SCHERZ, A. Light-dependent oxygen consumption in bacteriochlorophyll-serine-treated melanoma tumors: on-line determination using a tissue-inserted oxygen microsensor. Photochem Photobiol, v.65, p.1012-9, 1997.

ZORATTI, M.;SZABO, I. The mitochondrial permeability transition. Biochim Biophys Acta, v.1241, p.139-76, 1995. 